\title{
8. Scenes of secrecy
}

\subsection{Dissimulation and the secret}

"Dear Lord Nemessány, I know what I owe you, but for a while I need to dissimulate," writes Dániel Absolon to Bálint Nemessányi in a long letter on the Christmas of $1678 .{ }^{1}$ He enciphers the word dissimulation, becoming a showcase example for present-day research literature that considers the sixteenth and seventeenth centuries the par excellence age of dissimulation. $^{2}$

In the early modern period, „dissimulation” named not merely an ad hoc behavior, as it always had in Latin, but a cultivated courtly practice, which had rules of etiquette that could be systematized - an "art," as can be seen from Torqueto Acceto's 1641 book, the Della dissimulazione honesta. Courtiers and royals, officers and politicians, spies and ambassadors, philosophers and scientists always covered up their real motives and intentions in order to survive and step up on the career ladder. People necessarily concealed their true motives, emotions, intentions and thoughts in diplomatic and commercial meetings, in wartime and at peace treaty negotiations, in discussing heritage and property issues, often showing something different to all of their communication partners at the same time. One needed to be able to control his emotions and behavior in order to play a proper role in his social or private life. In the big game of dissimulation at court the real emotions and thoughts were hidden behind the rituals of power, etiquette and conversation rules. In grand-scale politics the raison d'état was the cause for the diverse usage of dissimulation as the absolutist states were being established. However, such events happened not only in politics and court intrigue, but they were also part of other areas of life.

Dissimulation and secrecy were intertwined in practice. Faking is concealing the real thought, emotion or intention in such a way that makes even the act of faking secret and unknown. So does dissimulation have a similarly close relationship with the main written tool of secrecy, cryptography?

1 MTT III. vol. 22. 443-446, 7 .

2 Brief selection from the literature of dissimulation: Perez Zagorin, Ways of Lying: Dissimulation, Persecution and Conformity in Early Modern Europe (Cambridge, MA, 1990) 1-14; Jon R. Snyder, Dissimulation and the Culture of Secrecy in Early Modern Europe (Berkeley: University of California Press, 2012); Carlo Ginzburg, Il Nicodemismo: Simulazione e dissimulazione nell'Europa del '50o (Turin: Einaudi, 1970), Vígh Éva, Barocco etico-retorico nella letteratura italiana, (Szeged: JATE Press, 2001). 
Can any conclusions be drawn from the fact that the only enciphered word in Absolon's letter is "dissimulation"? I am not aware of any studies on this problem, although it seems to me a crucial issue in the two hundred years between 1500 and 1700 , a period that was the heyday not only of dissimulation but also of cryptography.

Jon Snyder, a historian studying the early modern "art" of dissimulation, contrasts it with wearing a mask. If you put on a mask, you are being honest about covering your real face. Anyone looking at you will know that they do not see you as you really are. If you dissimulate, however, you act as if you were not hiding anything, as if wearing an invisible mask that still covers you. ${ }^{3}$ This is what made life difficult for those who lived in the age of dissimm ulation: they did not know what was underneath the masks, and they did not know who was actually wearing a mask and who was not.

In this way cryptography seems to be rather different: it does not cover up its ruse, but in fact advertises it. It is not cryptography (the concealing of messages in an obviously secret code), but rather steganography (the concealing of the existence of messages altogether, or the hiding of secret messages in apparently non-secret text) that corresponds to this activity. Cryptography transforms an accessible text into a code that is no longer legible to everyone, but which is self-evidently a cipher. Seeing an encrypted message motivates one to break the code, whereas in contrast, by hiding the fact that a message is present, steganography yields no such motivation. While enciphering results in a message that is clearly wearing a mask, steganography dissimulates (so to speak) even the mask. It is thus more effective if real hiddenness is a concern.

Technically speaking, steganography may be done in various ways. Ancient messengers were said to have written messages on their scalp, which was then hidden behind their growing hair (although this may be an altogether unlikely scenario). Another more widespread technique was to use invisible ink or miniaturized letters, or in a way that the cognoscenti would know that they must read the first letters of every word in an innocuous open document to make up the true secret message. One might also write characters in bold, flagging the secret message in an otherwise non-secret text. An exciting Hungarian case of steganography is quoted by Miklós Bethlen in 1667 from a letter in which ciphers are not numbers, whole words stand for nomenclators. The result is a text which seems meaningful yet irrelevant, but with the aid of the key one could substitute the political and geographical names, and unfold the real message. Bethlen lengthily 
quotes the original letter, then tries to give meaning to it himself: "I scarcely understand Bory's letter. He writes, 'There was no hope concerning Palatinus's life, and if he dies, it is a major change, but it does not derogate the great power of the holy majesty of God. I judge it to be worthless to start trade from Moldova and Wallachia, and I hope it will have no development. Where does the poor landlord's fortune lie? Should they never bring a horse for a rider from there, you would not believe what pretty herds the good husbandmen raise here. It is different; I am not sure if You have understood; trade has started from Vienna as far as Constantinople. Whoever has the inclination and the funds, with this commodity one can afford horses and everything.' - These are the words of Bory which I cannot understand, for I do not have the clavis. By trade from Moldova and Wallachia, I suspect, he means the support of the Turks whom he does not like - in fact I have never liked them either; while I had been out there, they had not been thinking that way. By trade from Vienna he must have meant the status of France maybe that if we cannot help him, they may still agree with them. But this is just a guess, what he really meant by it, I do not know. Whatever is the case, we have done according to their resolutio written with clavis: we have called for Lord Baló today."4

This puzzlement of the author clearly shows that steganography is real dissimulation, pretending to be nothing, or something else. Cryptography by comparison is an honest genre: visible, if not legible. Dissimulation and cryptography are two faces of (the act of) secrecy.

\subsection{Communication in politics}

Secretiveness and secrecy are the inalienable parts of political communication, and should not be considered special or outstanding phenomena. Politics do not work without secretiveness. Private diplomatic correspondence, parallel negotiations carried out with different partners at the same time, espionage, envoy's messages sent from hostile, or even from allied, territories - none of these can be carried out without the different practices of secret. As we have seen at the beginning of this book, retaining, hiding or restricting information is power, power that forms a hierarchy, power that is the lifting and excluding tool of authority. ${ }^{5}$

4 Teleki 4, 78-80, 63.

5 Michael Jucker, "Secrets and Politics: Methodological and Communicational Aspects of Late Medieval Diplomacy," in Paravacini Bagliani, ed. Il Segreto / The Secret, 275-309; idem, "Trust 
The need to apply ciphers in political communication is indicated by a number of sources where 'clavis' and 'secret' are mentioned in the same sentence, or where a secret is said to be only shared with a cipher: "I have used a clavis to make this more secret. We pray to God that it would remain secret." "If I had a clavis to use in corresponding with Your Lordship, I could write about things that you would all need to know. You would be amazed at these things". ${ }^{7}$ Dénes Bánffy does not even feel the need to exx plain the reason for using a clavis:, "When writing about us, please use a clavis, because, etc., etc." ${ }^{8}$ The association of the two notions can be seen in this letter, in which almost every second word is encrypted (in italics). “...although Lords Béldi and Csáki were really accusing His Lordship, do not be afraid, for I have good will for you and I am saying it to you in summo secreto, but please do not tell this to anyone, quia totum negotium perdes, quia jam est in summo secreto determinatum, sed mihi interdictum, neque vobis adhuc revellem, per amorem Dei rogo, sit in secreto. (...) Nevertheless, I am asking Your Lordship to report secretum about Your Lordship only to your trusted people lest they would gossip about the secret annuentia too soon, quia magnum esset periculum."

To be sure, enciphered correspondence was not the only tool applied in political secrecy, nevertheless, our analysis below will be limited to one issue: to what extent are cryptographic sources (cipher keys, enciphered letters, and other sources about the use of ciphers) informative about the secret concept and practices of secrecy of the past.

An overwhelming majority, at least ninety-five percent of the cryptographic sources is political in nature. Private, scientific, magical and other kinds of cipher uses have also survived, but their mass quantity is negligible compared to that of political ciphers. Ferdinand I in Vienna, Rudolf II in Prague, György Rákóczi I and II in the Principality of Transylvania, and Imre Thököly in Northern Hungary used the same type of substitutions when corresponding with their generals, ambassadors and

and Mistrust in Letters: Late Medieval Diplomacy and Its Communication Practices," in Marco Mostert, Petra Schulte, Irene van Renswoude, eds., Strategies of Writing. Studies on Text and Trust in de Middle Ages (Utrecht 2008), 213-236; Jonathan Elukin, "Keeping Secrets in Medieval and Early Modern English Government," in Gisela Engel, Brita Rang, Klaus Reichert and Heide Wunder, eds. Das Geheimnis am Beginn der europäischen Moderne (Frankfurt am Main: Klostermann, 2002), 111-129.

6 Teleki 8, 78, 68 .

7 MTT II/3. 109, 91.

8 Teleki 5, 121, 74.

9 Teleki 8, 169-171, 146. 
agents as their Western European colleagues. Besides official diplomacy, the private correspondence of political nature among the aristocracy also exploited the opportunities that cryptography offered. In the letters of magnates and primates in the sixteenth-seventeenth centuries, Miklós Zrínyi, Mihály Teleki, Zsigmond Kemény, Ákos Barcsay, Mihály Apafi, Mihály Teleki, György Lippay, Péter Pázmány it was not uncommon to have a word, sentence chunk or complete sentence coded in the homophonic system.

Because of the high quantity and variety of sources, it is worth making distinctions between various categories: grand politics and interstate diplomacy, powerful barons' correspondence on internal affairs, the aristocracy's movements that sometimes resulted in a conspiracy or revolt, the generals' military correspondence, the envoys' reports, and espionage. There are no strict boundaries, though, and the numerous borderline cases prevent the historian from being strict in applying these categories. Does the enciphered letter of Miklós Zrínyi, ban of Croatia to György Rákóczi II, prince of Transylvania, fall in the category of interstate diplomacy, correspondence by the aristocracy, or a conspiracy against the Habsburgs? When Archbishop Péter Pázmány is writing to C. H. Motmann, his Italian trustee, or when György Rákóczi II is writing to Jónás Mednyánszky, his trustee in Vienna, do these fall in the same category as envoy János Pápai sending his report to Ferenc Rákóczi, or rather in the category of a Serbian secret correspondent reporting to the court in Vienna? Due to the existence of the many unclear cases, diplomatic-political correspondence is going to be discussed as one category, while a careful attempt will be made at treating intelligence and military sources separately.

Though the majority of all historic ciphers belong to this category, it may seem at first that it is rather monotonous in its use of secrecy and in its motivation. Most of political ciphers obviously hide secrets of diplomatic and political nature, the reason for encryption being, even more obviously, the effort to make a message inaccessible for political enemies. This is especially true for the envoys' messages: this kind of text happens to be less varied concerning its concept of secret.

It seems more relevant to study however (as has been done above), the advancement of the code systems, and one can conclude, among other things, that the differences are not only chronological by nature (the earlier systems being less improved), but also geographical. The envoy to Constantinople often received a more advanced clavis than his colleagues from other regions. Johann Malvezzi, envoy of Ferdinand I to the Porte, used a homophonic key with nomenclatures, nullities and misleading 
Latin words with different meanings as early as $1548-1549,{ }^{10}$ while Jacobus Curtis, Ferdinand II's agent in Poland, applied a monoalphabetic cipher even seventy years later - at least with numbers instead of graphic signs. ${ }^{\text {"1 }}$ The importance of foreign affairs influenced the level of technological development in other cases too. Ferdinand I used a homophonic clavis with his brother, Charles $\mathrm{V}^{12}$ but a monoalphabetic one with the voivode of Moldova. ${ }^{13}$

Geography, however, was not only relevant as the area where a cipher was being used, but also as its place of origin. The beginnings the history of Hungarian cryptography fall around the time of Matthias Corvinus' reign (1458-1490). In a letter book by Matthias Corvinus that contained the letters by the royal chancellery in the 146 os and 1470 o very simple cipher grid in the shape of a square was to be found (unfortunately, the binding of the codex perished together with the cipher, so it is no longer extant). It is a so-called pigpen cipher, next to which there was also an encrypted text of three Latin words, in which (supposedly Bishop Janus Pannonius, the first Hungarian poet) illustrated how the system worked. It read MATIAS SEX HUNGARIAE (correctly: Matias rex Hungarie). ${ }^{14}$
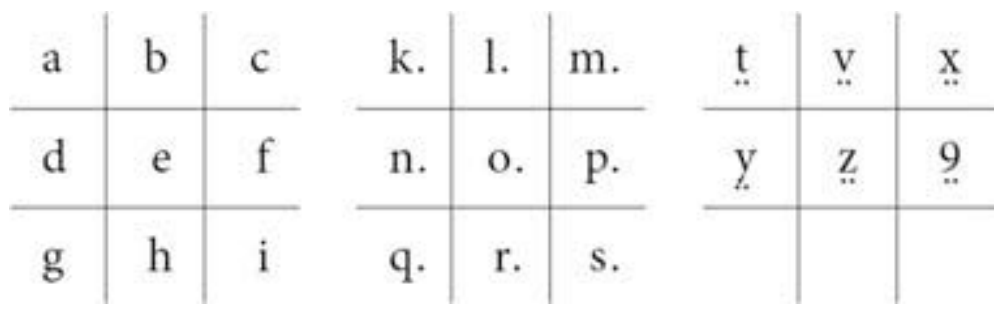

The cipher key of the letterbook ${ }^{15}$

10 War History Archives, 1548/3, Révay Titkosírások, 64-65; OSZK Quart. Lat 2254. 15.

11 HHStA, Ung Akt. Misc Fasc 422 Conv 1 fol 75 and fol $72-79$.

12 OSZK Quart. Lat 2254. 8 and 9.

13 OSZK Quart. Lat 2254. 17.

14 Décsényi Gyula, "Mátyás király leveleskönyve a gróf Khuen-Héderváry család könyvtárában" (King Matthias' letterbook in the library of the Khuen-Héderváry family) Magyar Könyvszemle 19 (1891): 169-175; Rácz György, A Héderváry-kódex hasonmás kiadása (The fac-simile editon of the Héderváry codex), in Héderváry-kódex. Mátyás király leveleskönyve a Héderváry család egykori könyvtárából (Héderváry-codex. Letter book of King Matthias from the late library of the Héderváry family) (Budapest: Magyar Országos Levéltár, 2008).

15 Décsényi, "Mátyás király leveleskönyve" 173. 
More serious encrypting methods were also in use in Corvinus' court as the letters of Matthias' wife, Beatrix of Aragon with his sister Eleanor, ${ }^{16}$ a 1491 note, also written by Beatrix in a book from the Corvinian library about Vladislaus arriving at Eger, ${ }^{17}$ and the cipher key of the ambassadors to Milan testify. ${ }^{18}$ All of these, however, were coming from Italy. Origin did play a major part in the quality of encryption.

This correlation can also be seen in the following centuries. Early modern cryptology in Hungary reached its zenith by the end of the period, in Rákóczi's time. Although high-quality ciphers can be found even from before that, these are again with Italian background, the homophonic system of Cornelius Heinrich Motmann from the 163 os being an example. ${ }^{19}$ Motmann provided Archbishop Péter Pázmány with information from Rome. The archbishop and his Italian correspondent used number bigrams (such as 24) to code the letters of the plain text: usually two bigrams were assigned to a letter, but some vowels got three, just like in an advanced homophonic clavis. They used a combination of one consonant and one number for syllables and a trigram of three numerals for code words, which were basically nomenclatures. These combinations were systematically assigned to letters, syllables or code words in numeric or alphabetical order. This kind of structure is easy to use but it is also vulnerable, although it only helps the codebreaker when a part of the key is already broken and the structure is recognizable enough. In this cipher, Motmann informs the archbishop of issues that are too private to be included in the official reports from Rome, or even in the plain texts of Motmann's letters: current events of Rome, diplomatic and legal problems related to Hungary. The high level of the encryption that was still rare in Hungary at the time was most probably due to the fact that Motmann was an experienced figure in Italian church diplomacy who acted as the agent for many a German high priest and ruler throughout the course of his life in Rome. ${ }^{20}$ Presumably

16 There are dozens of enciphered letters of Hungarian interest in the State Archives of Modena, a few of which have a microfilm copy in Budapest: MNL OL Microfilm 8620. For the letters, see the results of the Vestigia project: http://vestigia.hu/; and György Domokos, Norbert Mátyus, Armando Nuzzo, Vestigia - Mohács előtti magyar források olasz könyvtárakban (Pre-Mohács Hungarian sources in Italian libraries) (PPKE BTK 2015, Piliscsaba).

17 Miklós Vértesy, "Titkos írás egy Corvinában," (Secret writing in a Corvina) Magyar Könyvszemle, 77 (1961): 167-169.

18 Péter E. Kovács, "Corvin János házassága és a magyar diplomácia," (The marriage of János Corvin and the Hungarian diplomacy) Századok 137 (2003): 955-971.

19 Péter Tusor, "Pázmány bíboros olasz rejtjelkulcsa." Archives of the Archbishop AEV n. 148/3 and n. 159

20 On Mottmann, see: Tusor, “Pázmány bíboros olasz rejtjelkulcsa," 538-542. 
he did not receive the structure of his key from the Hungarian archbishop. More likely, he copied the structure of other highly developed Italian keys.

It is not an exaggeration to argue that the closer the origin of a cipher was to Italy, and the closer its intended place of use was to Constantinople, the more advanced its system was. An example for this rule is the big 1560 homophonic key of Baile Vettore Bragadin, delegate of Venice in Constantinople. ${ }^{21}$

But what happens when the classification of ciphers is made not only on the basis their level of development but also according to their content? It may seem that the messages studied so far say nothing new as for the concept of secret these historic figures had. The informant simply describes the news he has heard, the negotiations he has done, whereupon the addressee gives him coded instructions. A more careful analysis, however, shows a sophisticated picture concerning both the content and the reason for using a cipher. Practices of secrecy can be examined following two procedures related to each other: first a study of the geographical and political names and the most frequent concepts in the ciphers, in other words, some research into the nomenclatures, and second, a close reading of the enciphered content.

In her book, A rejtözködő murányi Vénus (The Hiding Venus of Murány) historian Ágnes R. Várkonyi emphasized the conclusions that can be drawn from the nature of nomenclatures. She called attention to the fact that some items of the code tables captured from the members of the Wesselényi movement illustrate well the members' political concepts, main goal and greatest needs: "against the Pagans=1576", "getting money=1615," "we are gaining money=1616". ${ }^{22}$

Name nomenclatures seem to be the most convenient in this respect. They show who counted as relevant political figures for the corresponding partners. More than once, secret communication started with changing the names in an otherwise plain text, and sometimes it did not even go further. As Ferenc Rákóczi is writing to the vice general in Kassa (Kosice, Slovakia), "We are sure you have received our letter about how to change the names in the communication with Poland in the future."23

21 Christiane Villain-Gandossi, "Les Dépêches chiffrées de Vettore Bragadin, baile de Constantinople (12 juillet 1564-15 juin 1566)," in eadem, La Méditerranée aux XIIe-XVIe siècles: relations maritimes, diplomatiques et commerciales (London: Ashgate Publishing, Limited, 1983), 52-106.

22 Várkonyi, A rejtőzködö, 214.

23 AR I. vol. 1. 664-66, 4. 
Both the political realities of a historical situation, and the expected frequency of a particular word in a given correspondence can be sensed on a cipher table: palatine Pál Esterházy and Mihány Apafi put "mining towns" and "frontier militia" in their keys, ${ }^{24}$ the only fifteen nomenclatures that Ferdinand I and Charles V used in a cipher included: "madame nostre tante" and "lutherien", ${ }^{25}$ whereas "tartari" is one of the twenty-three nomenn clatures on the clavis of Ferenc Rákóczi and the envoy of the Russian tsar. ${ }^{26}$

Good example is another of Rákóczi's tables. Its few nomenclatures nicely map up the main foreign relations during the freedom fight: Imperator, Rex. Rom, Pr. Ragozi, Turca, Bavarus, Rex Prussiae, Sveciae, Poloniae, Galliae, Angliae, Belgium, Hungaria, Austria, and Transylvania. ${ }^{27}$ A thorough comm paratistic research into the tables of the freedom fight would vividly show the way the prince was maneuvering and looking for allies and how his tactic changed in space and time. ${ }^{28}$ The sophistication of the nomenclatures and the quality of the claves also mark the importance of a particular diplomatic relation. The prince used a much more primitive code table with the Russian tsar than with his other allies, as if it had been more than satisfactory to use graphic signs in a monoalphabetic system in this direction. ${ }^{29}$

A close look at the encrypted content yields in some cases results similar to the study of the nomenclatures. One letter from Dominique Reverend to Mihály Teleki for example only encrypts the key names: Dominus Nalassi, Rex Galliae and Marchionis de Béthune..$^{30}$ Similarly, an extensive study of Teleki's letters shows that the most frequently ciphered items are key words, places, names of people, money and time, and in general, political figures, exactly what can usually be seen in a nomenclature table. The fact that the enciphered parts are similar to nomenclatures is obviously the result of the users often restricting their encryption activity to the nomenclatures. It saved them time and characters to only replace a couple of names with numbers. Arriving to a partial encryption of a given text, there seemed to be no need for the arduous job of encrypting the other words character by character. This negligence of the scribes sometimes resulted in the

\footnotetext{
24 MNL OL P 125 No. 119775 ,

25 OSZK Quart. Lat 2254. 8

26 Ráday Archives C64-4d2-25. 16.

27 Ráday Archives C64-4d2-25. 3.

28 Ferenc Tóth, Correspondance diplomatique relative à la guerre d'indépendance du prince François II Rákóczi (1703-1711) (Paris-Genève: Honoré Champion, 2012).

29 MNL OL G 15 Caps. C. Fasc 43. and Ráday Archives C64-4d2-25, and the back of Ráday Levéltár C64-4d2-25. 8.

30 Teleki 8, 121, 112.
} 
fact that even the encrypted nomenclators were easy to reconstruct based on the rest of the plain text. This is rather intellectual than technical carelessness - the scribe does not make the effort to step into the shoes of his adversary, and does not examine what could be understood from the letter without the help of a key.

This limited use of enciphering, nevertheless, was not typical. There were great variations as to the quantity and quality of cipher being used, according to the person of the author or his situation. They can be observed in the correspondence of Dániel Absolon and Mihály Teleki. Absolon is very economical in all his letters, encrypting only the key concepts either with nomenclatures, or by concisely spelling it ("the Polish king", "prince of Transylvania", "His Majesty" "business of Hungary", "on his part", "Lord Macskássi (...) is ready per occultos canales to help his lordship's business", etc. $)^{31}$ Teleki, by contrast, uses ciphers a lot more frequently. Beside the names of politicians, he encrypts complete sentences, descriptions, characterizations, so the result is a letter in which one third or even half of the text is enciphered.$^{22}$ Imre Thököly - this time in a letter to Teleki - acts similarly. He does encrypt a lot of text: complete paragraphs, or just a couple of sentence fragments, but so many of them that no one has any chance to understand the letter without the key. ${ }^{33}$

Are these differences a matter of personal taste in ciphering strategy? Or are these connected to the fact that major political figures such as Thököly and Teleki employed a secretary, while simpler correspondents like Absolon did the encryption themselves. Not quite so. It has been already shown that being high on the social ladder did not necessarily exempt one from the manual tasks of cryptography. Thököly, too, often did the job himself. It seems rather likely that they were more sensitive in secret matters than Absolon. Why Teleki used a more advanced cipher when writing to Absolon than to Apafi probably has political reasons and must be answered by the nature of each letter's content. He must have found his own secret he shared with Absolon more valuable than the future prince's secret to which he refers in writing to Apafi.

The ciphering ratios are similar in the correspondence of Prince György Rákóczi I and his envoys. The envoys are economical with the encryption,

31 Teleki 7, 371-373, 272. On the correspondence of Absolon and Teleki, see: Lajos Hopp, "Sobieski és a 'magyar malkontentusok' a barokk politikai irodalmi hagyományban (Bécs, 1683)" (Sobieski and the 'Hungarian malcontents' in the baroque literary tradition) Filológiai Közlöny 30 (1984): 1-24.

32 Teleki 8, 202-206, 168.

33 Teleki 8, 143-144, 127. 
trying to limit it to place names, peoples' names, numbers, and data concerning military power. The prince, in contrast, uses his code tables more often, more extensively and more cleverly, though he does not encipher complete letters or paragraphs either. ${ }^{34}$ The smartest cryptologist, nonethee less, is Archbishop Péter Pázmány, who uses a combination of good-quality clavis and carefully selected parts of the text. While Rákóczi relies on four different equally outdated monoalphabetic keys, Archbishop Pázmány only has one, but that is a tough homophonic one..$^{35}$

Encrypting critical statements, concepts and names in the main body of a letter was just one widely-used method. Another strategy involved leaving the full body of a letter as a plain text, and only putting the post scriptum in cipher. Political actors of the late seventeenth century, Dénes Bánffy, ${ }^{36}$ Imre Thököly ${ }^{37}$ and Simon Kemény, ${ }^{38}$ all have letters following this procedure. The post-scriptum in these cases involves various topics: the trustworthiness of a third party, the space and time coordinates of a meeting, or just information that does not even seem to be sensitive today. The relationship of the plain text of a message and the encrypted note is especially interesting in a letter by Simon Kemény. There is a mysterious sentence in the short letter ("No doubt that you should not be bothered by the Fox on the sides of the fortress, but if I were you, I would surely set up that trap.") which becomes meaningful when one reads the encrypted post-scriptum: "By the name of the Fox you should mean Sigmond Bánf." ${ }^{39}$

The encrypted secret - as also seen in the previous example - often warns about an untrustworthy figure, a supposedly malicious and possibly dangerous person: a warning goes in this way: "As for you, my lord, you surely have a great many adversaries, ${ }^{m 0}$ and like this: "let us be very careful about these three: 1. Veselényi, because he is evil, 2. the Porte, 3. the peace we have with the Turks now."14

34 Ötvös, Rejtelmes levelek, 27-156, Révay, Titkosírások, 76-86. For Rákóczi, see Gábor Kármán, Erdélyi külpolitika a vesztfáliai béke után (Transylvanian foreign policy after the peace of Westphalia) (Budapest: L'Harmattan, 2011), 33-118.

35 Ötvös, Rejtelmes levelek, 1-4, Révay, Titkosírások, 87-107.

36 Teleki 2, 323-324, 244.

37 Teleki 8, 173-175, 150 .

38 Teleki 2, 266-268. 196.

39 Teleki 2, 262, 192.

40 Teleki 8, 114-115, 106.

41 Sándor Szilágyi, "Herczeg Rákóczy Zsigmond Levelezése," (Correspondence of Prince Zsigmond Rákóczi) MTT III/11. 288-289, 102. For the distrust between the prince and Wesselényi, see also Kármán, Erdélyi külpolitika, 214-215. 
In many cases the secret writing is not used to cover up a secret as much as to defend oneself or others. It is a tool that prevents the writer (or the person he names) from getting into a delicate situation in case the letter got into the hands of illegitimate readers. Scribes often encrypt those names that they share sensitive information about. ${ }^{42}$ The following sentence from Mihály Teleki is an illustration of approaching authority carefully and self-defensively: "The prince is mortal too, if he happens to die, there is a new prince." ${ }^{43}$ Similarly, he writes in another letter, "Believe me, this aforementioned princess if she finds a way, as she already started, will steal this captainship from me." 4

The relationship of the cipher and the concept of secret is particularly relevant in the case of a major statesman, poet and military leader of the mid-seventeenth century, Miklós Zrínyi (1620-1664). Although his agent from Sopron, the lawyer István Vitnyédi asked a clavis from him more than once, ${ }^{45}$ and did correspond with a clavis himself, ${ }^{46}$ no trace survived that Zrínyi, ban of Croatia ever answered him using a cipher. Most probably these letters were lost. All of the half dozen extant enciphered letters by the ban were addressed to the same person, György Rákóczi II, prince of Transylvania.

This correspondence of Zrínyi, ban of Croatia and Rákóczi, prince of Transylvania is among the most carefully studied chapters of Hungarian history. ${ }^{47}$ Although theirs obviously must have been a two-way communit cation, none of the princes' letters to Zrínyi have yet been found. All of the ban's enciphered letters used the same code key, ${ }^{48}$ a then-up-to-date hoo mophonic clavis of Latin letters. It assigned three numerals to almost all of the letters and used some thirty nomenclatures, making it a table of nearly ninety code signs. This could be adequately safe were it not for three things.

MTT III. vol. 22. 441-442, 5, and Teleki 8, 175-176. 151 .

Teleki 2, 578-579, 394.

4 Teleki 2, 586-589. 400.

45 András Fabó, "Vitnyédi István levelei," (Letters of István Vitnyédi) MTT II/3. 237-239, 229.

MTT II/4. 37-41, 261. See also Gergely Sárközi, "Álhírek és valóság."

46 Fabó, “Vitnyédi István levelei," MTT II/3. 256-257, 245; MTT II/4. 64, 285; MTT II/4. 63-64, 284; MTT II $/ 4.65,286$.

47 Katalin Péter, “Zrinyi Miklós terve II. Rákóczi György magyar királyságáról," (Mikós Zrinyi’s plan on György Rákóczi’s Hungarian reign) Századok 106 (1972): 653-666, Levente Nagy, Zrínyi és Erdély. A költó Zrínyi Miklós irodalmi és politikai kapcsolatai Erdéllyel (Zrinyi and Transylvania: the poet Zrinyi's literary and political relations to Transylvania) (Budapest: 2003); Kármán, Erdélyi külpolitika, 276-295; Révay, Titkosírások, 109-123.

48 Károly Széchy, Gróf Zrínyi Miklós 1620-1654 (Count Miklós Zrínyi 1620-1654) vols. I-V kötet (Budapest: Magyar Történelmi Társulat, 1896-1902). 
First, the homophones assigned to one particular letter are obviously related, ending in the same numeral. (A: 1, 11, 21, E: 5, 15, 25, 35). Second, the numbers are assigned to the letters in a predictable order. Third, nomenclatures are three-digit number and are consequently easily discernible from one or two-digit letter signs. ${ }^{49}$ Still, we must give credit for the nomenclaa tures - some of the numbers are still left unbroken, leaving the identity of the person behind it unknown.

Zrínyi was fully aware that his rival, in his case his direct superior, the Habsburg court, will not be confused by the cipher, as traffic analysis in itself could be used against him. The mere fact that he exchanges enciphered letters with the prince of Transylvania, ruler of an adversary country, could have been perilous to him. He does discuss this danger twice. Once in a postscript in 1654: "Dear lord, do not be offended that I am not writing very frequently, I would be in great danger if my correspondentia with you was revealed. I can serve you better if my service to you is kept secret." And again in 1655: "I would be lucky if I could tell you my sensus in person. I cannot trust this to a letter or any kind of character. I must wait for God, time and good luck."

Zrínyi was economical and strategic in his ciphering. He wrote his letters himself (they all survived in his own handwriting except for one). He mainly used nomenclatures, and assigned several of them to the names of the most important persons of the actual confused political situation: Archbishop Lippay - 219 and 450, Puchaim 217 and 40o, his own name, Miklós Zrínyi - 270, 515, his addressee, the prince of Transylvania - 26o, 310 and 510. The number 375 is still left unbroken from one of his letters.

When necessary, he makes use of the code alphabet to translate the most sensitive parts of the plain text character by character. Some of these are negative remarks about the Habsburg court, "All of Europe is watching the debility of the house of Austria" (...) "The emperor is sickly and weak and everybody thinks he will die soon. ${ }^{\text {"50 }}$ There are also remarks about members of the aristocracy that happen to be on the other side of an internal conflict, "Archbishop, Puchám are plotting something, we shall see, quid parturiunt, both are with great exhibito towards me, as I am to them. I don't suppose that they believe me, but I don't believe them either. Trust me, the cancellarius is very deceitful, he has made us all believe that the prince of Transylvania listens to him and that he can control him. ${ }^{n 1}$ Elsewhere he warns 
the prince that the Judge Royal had shown the court what the prince had written to him, "The letter you had written to Nádasdi he had immediately sent to the court, I do not know what is in it but there is much ado about it and they are afraid. ${ }^{52}$ In general, he only hides information that is of high relevance politically.

A special case is the so-called "memorandum on the palatine" that is a highly ambiguous letter. No manuscript of it survived, it is only known from the publication of the nineteenth century historian, Kálmán Thaly. ${ }^{53}$ In this lengthy letter Zrínyi allegedly offers cooperation to the prince of Transylvania, an offer that would have been equal to a death sentence if it had been found out either by the Habsburgs. One would expect the whole letter to be encrypted, yet we find a surprising method of encryption, one that Zrínyi never used elsewhere. ${ }^{54}$ The letter begins in the usual way, with three-digit numbers substituting the names of the major political figures. These numbers look as if they had been taken from the nomenclature table that Zrínyi was using in his authentic letters. Yet, the names of the prince of Transylvania and Zrínyi appear as plain text, while they are coded in all the other letters we have. Certain code numbers appear here that none of the other letters contain, ${ }^{55}$ their meaning is revealed in Thaly's publication as if they had been given in the manuscript. The most important number, 445 , the code for the person who would be - in Zrínyi's opinion - the only suitable person for the position of palatine, is not given. Beside the nomenclatures, some other parts of the text are spelled letter by letter, following a procedure familiar from the other letters of Zrínyi, but oddities occur. There is no reason, for example, in only coding the letter $v$ at the beginning of the word venné (he would buy). Beside the code ooooo (Puchaim), often used in the other letters, in the "memorandum on the palatine" the code ooo (emperor) also appears,

52 Széchy, Gróf Zrínyi Miklós, vol. 4. 268

53 Kálmán Thaly, “Gr. Zrínyi Miklós emlékirata." (The memorandum of Count Miklós Zrinyi), Századok 1868, 633-648.

54 Ágnes R. Várkonyi, “Az elveszett idő: Zrínyi Miklós nádori emlékirata?” (The time lost: a memorandum of Palatine Miklós Zrínyi?) Hadtörténeti Közlemények 113 (2000): 269-328, particularly: 291. See also eadem, "Navigare necesse est: A Nádori emlékirat az újabb kutatások koordinátáján," (Navigare necesse est: The memorandum on the palatine in the coordinates of the most recent research) in eadem, Európa Zrínyije (Europe's Zrinyi) (Budapest, 2010), 346-283; Gábor Várkonyi, "Emlékirat a nádorság ügyében," (Memorandum in the issue of palatineship" Irodalomismeret VI (1995): 40-47.

55 Historian Ágnes R. Várkonyi has made a complete list of these: Várkonyi, "Az elveszett idő," 290 . 
which in quite arbitrary and confusing. While Zrínyi had written the other five partially enciphered letters with his own hand, here there is no sign that he had done the same, all the more so as the letter names him in third person singular.

Use of secrecy is even more shocking in this memorandum than these technical details. The most sensitive parts of the letter, including the names of Zrínyi and Rákóczi, are left as plain text. In contrast, there is a diligently encrypted note about the marriage of a nobleman's daughter that any contemporary could easily have learned about. The servile attitude that characterizes all of the letter would have been so compromising for the ban, had the letter been captured that hiding the details of the royal family's marriage customs (that is also enciphered) was a totally unnecessary precaution. One also wonders why the two long enciphered parts of a lengthy letter full of internal politics are on the topic of marriage. And the list of problems goes on, as historian Várkonyi has compiled it in a long study: the suspicious lack of the original source, the suspicious historian, and known fabricator, Kálmán Thaly's central role in "finding" the letter, the unusually submissive role Zrínyi seems to play, the illogical structure of the letter that is so atypical of the ban, and so on. When adding all of these to the analysis of the cipher and of the author's concept of secrecy, one can be convinced that this letter is of dubious origin, to put it mildly. It could, nevertheless, have been 'stitched together' by Kálmán Thaly from several other texts by Zrínyi in order to serve as an argument for the historian in a late $19^{\text {th }}$ century scholarly debate. ${ }^{5}$

Zrínyi's clavis had only been known in a reconstructed form until very recently the original table of letters was found (in the course of my own archival research), unfortunately without the nomenclature table. It is a great loss because it could help identify the reference for 375 , and it would clarify whether the nomenclatures only existing in the memorandum such as the mysterious 445 had really been part of the original clavis or whether they had been made up by Thaly..$^{57}$

56 On Thaly's literary fabricates and unreliable and dubious historical scholarship, see Ágnes R. Várkonyi, Thaly Kálmán és történetírása (Kálmán Thaly and his history writing) (Budapest, Akadémiai Kiadó, 1961).

57 ÖStA HHStA Ungarische Akten Specialia Verschwörerakten VII. Varia Fasc. 327. Konv. D. Chiffres 1664-1668, fol 15 . 


\subsection{Military operations and espionage}

Secrecy concepts of generals sending encrypted messages to each other from stormy battle zones seem as monotonous as those of the diplomatic sources seemed at first sight. Rákóczi's generals for example restricted their correspondence to the size of the enemy's army, to coordinates of their passage, to military news to be verified and to details of discipline issues in the army. ${ }^{58}$ Taking a closer look, however, soon reveals a few interesting details, just as it did in the case of political letters. The method is similar, too. First, nomenclatures are studied, then the ratio and length of enciphered and plain text paragraphs.

The results are intriguing. In politics, the recurrent motivations werebeside forwarding a specific diplomatic message-warning, carefulness and avoiding danger. In military communication, the main themes are-beside passing on data of technical nature-fear, being threatened, and covering up weakness, sickness or cowardice on the writers' part.

Ciphers often become crucial when the enemy encircles the letter writer and his troops. Ferenc Palkovics, inspector writes to General Bottyán, "In case the enemy will encircle us, make claves and use them to write to us." (The envelope reads, "Judge of Madocsa, pass this letter on secretly today or you will die. Cito, cito, cito, cito. Citissime, citissime, citissime, citissime.") $)^{59}$ In the spring of 1710 the increasingly threatened Rákóczi instructs the commanders of Érsekújvár to use claves too. ${ }^{60}$

Danger engenders fear. Fear generates stiff, enforced and abundant encryption. There are only one or two plain text words in the one-page handwritten letter of Kata Bornemissza, who has every reason to worry in the year characterized by political and military turmoil, and often called the most tragic year of the history of Transylvania. In her letter sent to her older brother, Mihály Teleki, almost everything is coded, for example, "I fear that your help will never arrive." ${ }^{\text {61 }}$ The same person, in contrast, will only encrypt one or two words in normal circumstances. ${ }^{62}$

$5^{8}$ War History Archives E. 1705/4-17.

59 AR I. vol. 9. 714-715, 538 .

6 Kálmán Thaly, "Érsekújvár utolsó magyar várparancsnokainak utasítása," (Orders to the last Hungarian commanders of the fortress of Érsekújvár) Hadtörténelmi Közlemények 1889, 44-45, no. 20.

61 Teleki 1, 402-403, 354.

62 Teleki 1, 220-221, 191. 
In a threatening warlike situation, particularly when someone is surrounded by the enemy, it is a question of life and death not to disclose information on his weakness and beaten-up state. In a long letter that the Hungarian "fugitives" wrote to Mihály Teleki, relatively little (military) information is encrypted, but the following words are: "although, according to a bad Hungarian tradition, only one third of the army came out of the camp." ${ }^{\prime 63}$ Towards the end of his long freedom fight, Rákóczi is writing in 1710: "the enemy is pushing us down from that territory" ${ }^{64}$ During the next month the prince sends several similar letters, most of which are plain texts, but those few sentences that are encrypted all describe their own military weaknesses, "The praesidium has left Huszt," "we won't help Ujvár," "65 "not more than 33 has been left at camp," "do not expect any more help from me," "no armies are left anywhere," "the dragoons are secretly leaving," "Kassa deperierit, there are not more than 500 soldiers left. ${ }^{166} \mathrm{In}$ this final, doomed phase of the freedom fight it was important to conceal the details on the fighters' weaknesses not only from the enemy but also from the personal messenger of the prince in order to prevent disparaging talks from spreading among the militia.

The best-known example of concealing one's own weakness is the oft-quoted last letter of the famous general János Bottyán sent from the fortress of Szentlőrinckáta, dated 18 September 1709. There is only one enciphered sentence in this letter: "I am sick and cannot get out of bed because of an illness that hit me a couple days ago: if the barbers had not bled me, I might even have died. ${ }^{, 67}$ The sickness did indeed prove fatal in his case six days after the letter was written.

The spies' reports reveal another kind of secret concept, though fear is not missing from these letters either. History of intelligence services, including espionage, used by early modern states, is fairly well documented. Charles Howard Carter wrote about the secret diplomacy of the Spanish Habsburgs between 1598 and $1625,{ }^{68}$ while Paolo Preto revealed the works of the spy agency of Venice. ${ }^{69}$ In the last two decades considerable research has been carried out concerning the intelligence activity of the

\footnotetext{
63 Teleki 8, 343-347, 316.

64 AR I. vol. 3. 152-154, 94.

65 AR I. vol. 3. 160-162, 99 .

66 AR I. vol. 3. 169-172, 104.

67 AR I. vol. 10. 51-52, 22.

68 Charles Howard Carter, The Secret Diplomacy of the Habsburgs, 1598-1625 (New York: Columbia University Press, 1964.)

69 Paolo Preto, I servizi segreti di Venezia (il Saggiatore, 1994).
} 
Ottoman $^{70}$ and Habsburg ${ }^{71}$ empires, a number of new sources have been studied, quickly making these areas well documented..$^{72}$

Secret networks of spies, agents, and correspondents (Geheimagent, secretarius explorator) were enmeshed in the territories between the Habsburg and the Ottoman Empires, including the Kingdom of Hungary and Transylvania. When a new agent was roped into the system of correspondents, the encoding system was fixed. ${ }^{73}$ The scope of espionage extended well beyond sheer diplomacy; it involved all strata of society - local doctors, merchants, soldiers, ambassadors' interpreters, that is, everyday people far from the diplomatic hierarchy - who risked their lives collecting and transferring information. Thanks to their professions, their frequent travels did not cause much suspicion (as opposed to someone like a farmer, who would have looked awkward if he had taken part in an extensive correspondence, many meetings and much traveling).

The spies in the region were most often people coming from the border regions of the European and Turkish cultures, most frequently of southern Slavic (Serbian, Bosnian) origin, in other cases they were Armenians, Sephardi Jewish doctors, or Christian renegades who fled to the Turks. Often the same families provided several generations of agents. Because one never knew if a letter had been successfully delivered, their reports were often sent in three to six copies. The spies from Constantinople regularly sent their reports via Venice, Ragusa or Split. There are signs that the Signoria of Venice took the opportunity to break the messages.

The reports most often included political information and were written in Italian. The authors wrote sparingly about themselves, partly self-defensively. Those few sentences that are there, however, help create a vivid picture of their fears, education or linguistic skills, knowledge of the Bible, history and geography, religious and cultural background, their fees, the threats surrounding them. It is also relevant, how seriously the

70 Gürkan, "The efficacy of ottoman counter-intelligence;" Dávid - Fodor, "Oszmán hírszerzés"; Ágoston, "Információszerzés és kémkedés az Oszmán Birodalomban," Dejanirah Couto, "Spying in the Ottoman Empire."

71 Žontar, Obveščevalna služba in diplomacija avstrijskih Habsburžanov; Fodor, "Kémkedés," Szakály, "Egy végvári kapitány. Petercsák and Berecz, eds., Információáramlás. Kerekes, "Kémek Konstantinápolyban."

72 Bagi, "Határvidéki és diplomáciai kémkedés."

73 Kerekes, "Hírszerzés a XVI-XVII században;" eadem, Diplomaták és kémek; Petercsák and Berecz, Információáramlás. One example for original and solved letters from 1632: ÖStA HHStA Staatenabteilungen Türkei I. Kt. 112. Konv. 5. fol. 1-9 and fol. 17-28. 
information arriving with their help was taken by the Habsburg court and how urgently the Hofkriegsrat, the Court Council of War had them decoded. ${ }^{74}$

\subsection{Love, politics and male bonding}

The best-known European example of combining love, politics and cryptography is the encrypted correspondence of Anna of Austria, the queen regent of France and her minister, the cardinal in charge of the country, Mazarin in the years around 1651. Emotional secrets were just as important in their correspondence as political ones. Modern publishers realized early on that the authors used separate codes, nomenclatures to express their attachment, friendship and love. Most of the farewell parts are left open, but they used numbers to name themselves, and broad graphic signs for encoding their own emotions. It seems that both Mazarin and the queen had used professionals (the most famous of whom was Antoine Rossignol, the designer of the "Grand chiffre" of Louis XIV) to help them in their official ciphered correspondence, yet they did the encoding and decoding themselves when writing letters about their own covered-up emotions, making these a nice example of how to express gentle love with the help of nomenclatures. ${ }^{75}$

There is a similar secret love affair in Hungarian history. Two beautiful cipher tables survived from the archives of the Rákóczi freedom fight on parchment (as opposed to the much more common paper) and in colored ink. One of them, the famous flower-patterned clavis, a sophisticated homophonic system, was used for important negotiations with his main ally, the French king, Louis XIV. ${ }^{76}$

74 Kerekes, "Kémek Konstantinápolyban." The collection of deciphered spy report from Constantinople from the years 1684-1696: Archiepiscopal Library of Esztergom, Ms. II. 303. On microfilm: MTAK Mf. 5528-5529.

75 Claude Dulong-Sainteny, "Les signes cryptiques dans la correspondance d'Anne d'Autriche avec Mazarin, contribution à l'emblématique du XVIIe siècle," Bibliothèque de l'école des chartes 140 (1982): 61-83.

76 MNL OL G 15 Caps. C. Fasc 44, Révay, II. Rákóczi Ferenc, 68 and 84. 


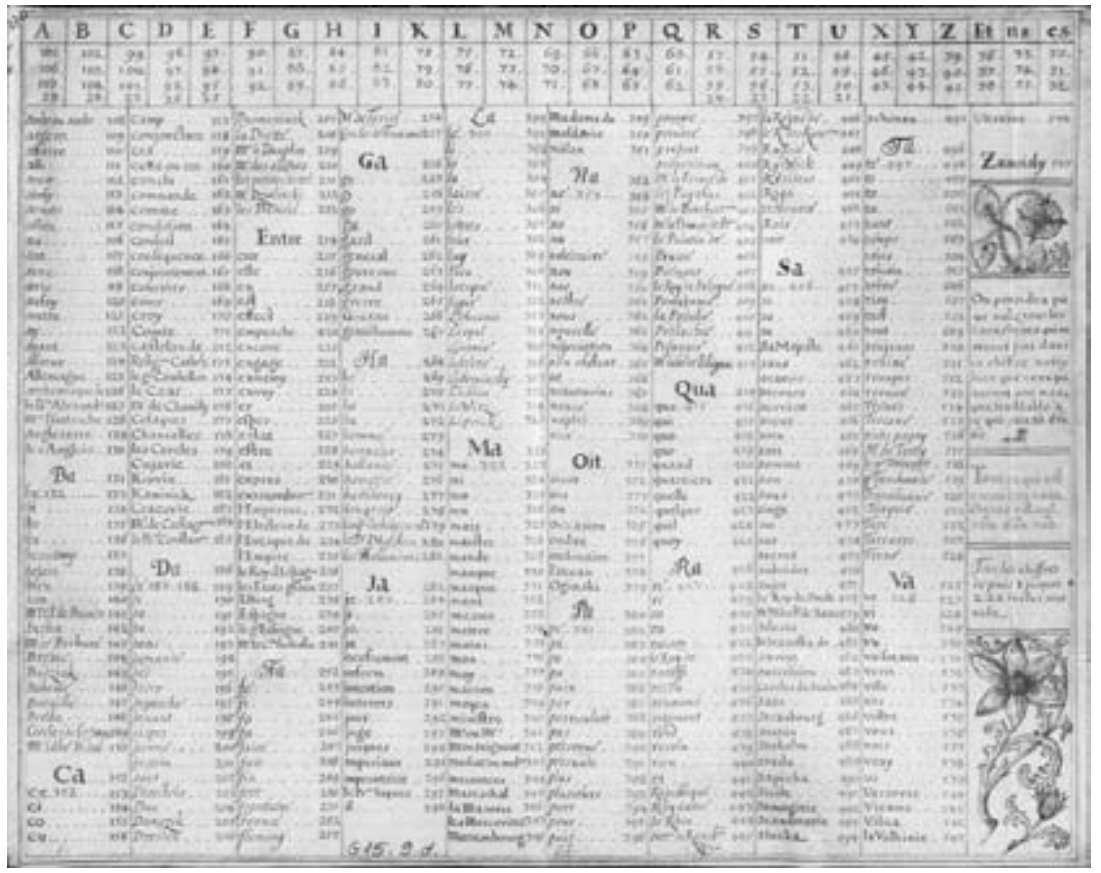

The code key of Rákóczi and Louis XIV

The other clavis under study is in French too, and it is nearly as beautiful. It is also copied on parchment, it is also homophonic, and it is almost as extensive as the previous one, containing circa three hundred fifty elements. Yet we find a few odd items among its nomenclatures. While the previous code table of the French king assigns number codes to geographical and political names, here only two cities belonging to the Polish-Lithuanian Commonwealth, Krakow and Warsaw appear as place names, and there are hardly any political figures named. In addition, there are a few unusual words among the frequently used nomenclatures, such as "abandonne", "adorable", "chagrin", "jaloux" "solicitude", "sentimans", "souvenir". There is no clue as to the recipient of these special letters encrypted with this code, but it must have been someone close to the prince's heart. ${ }^{77}$ 


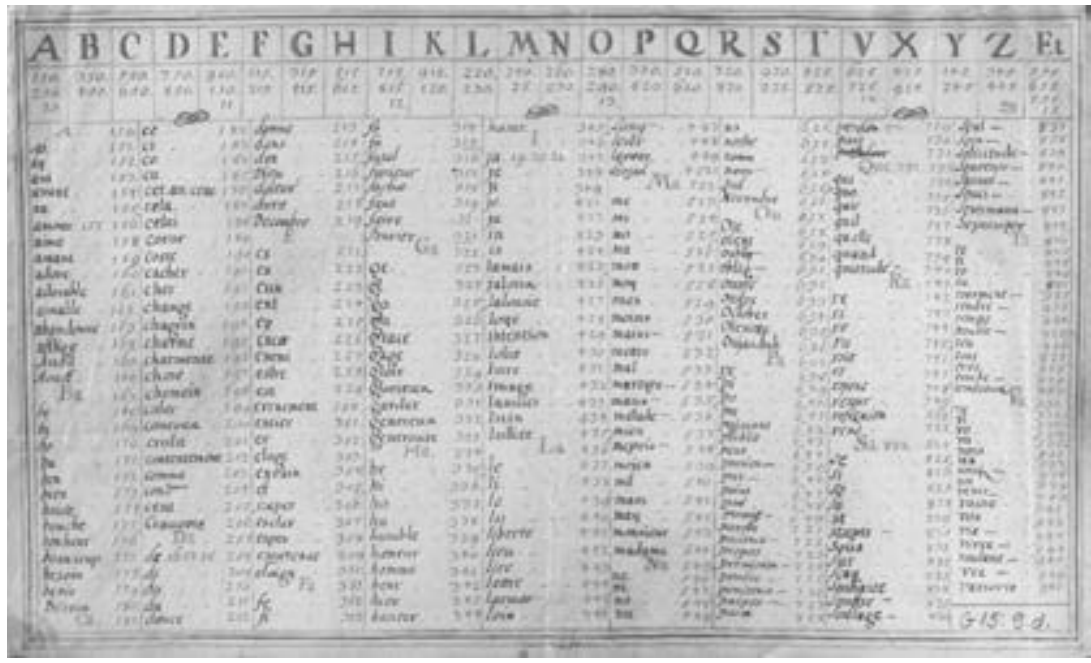

The anonymous code key of Rákóczi on parchment

There is, however, in the same archive another version of this mysterious table copied on paper. It is similarly anonymous, but it has a love letter written on its back. ${ }^{78}$

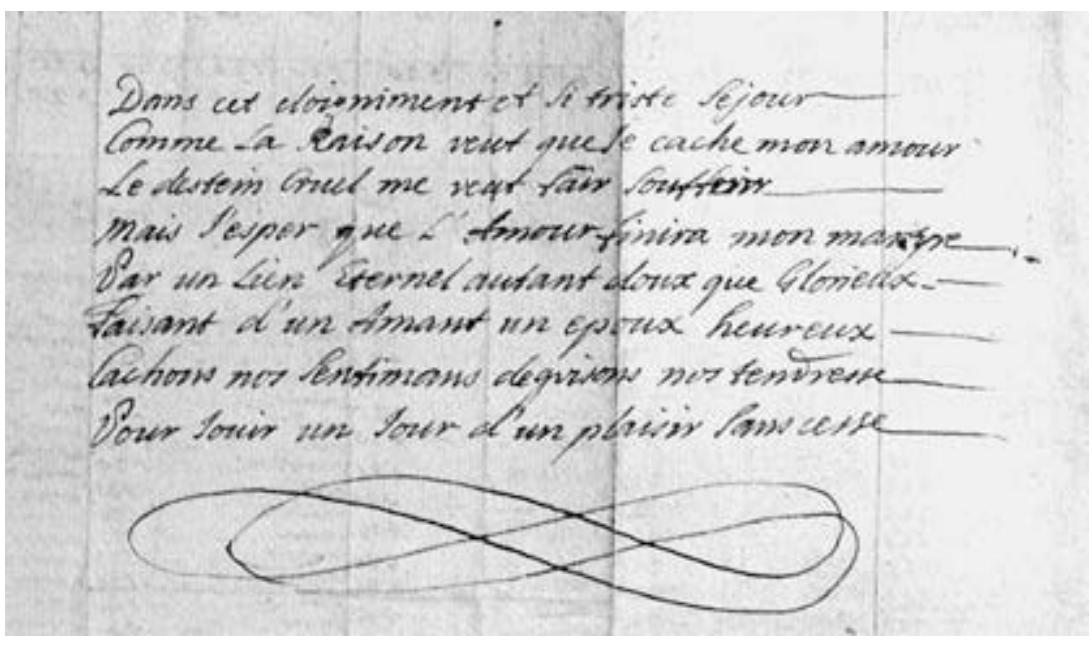

The poem, surviving in the prince's handwriting, looks very eloquent at first sight, yet it contains a number of metric mistakes that no native speaker 
could have made. The poet, for example, does not know that the normally silent $e$ letters at the end of a line in French poems are always pronounced. It is well known that Rákóczi, partly due to the special circumstances of his education, considered French, along with Latin and Hungarian, as one of the most important languages in which he could express himself. French was the most important diplomatic language for him, and he used it to communicate with his sons, who did not speak Latin or Hungarian. But just as with Latin, in the case of French, Rákóczi was content with a relatively high level of knowledge, and he did not wish to achieve perfection..$^{79}$ All of these make it very likely that this imperfect yet expressive verse is not only copied by him, but it is Rákóczi's own poem:

Dans cet eloigniment et sí triste Sejour

Comme la Raison veut que je cache mon amour

Le destein cruel me veut fair soufferir

Mais J'esper que l'Amour finira mon martyre

Par un lien Eternel autant doux que Glorieux

Faisant d'un Amant un epoux heureux

Cachons nos Sentimans deguisons nos tendresse

Pour jouir un jour d'un plaisir sans cesse.

In an approximative English translation:

In this gloomy loneliness, in this sad journey

When reason calls me to hide my love,

Cruel destiny has sentenced me to suffer.

But I hope that my martyrdom will end

And the sweet, glorious eternal bond of love

will make me a merry spouse at last.

So let us wear our masks and disguise our desires

And wait for the day when endless joy we receive.

As a historian has pointed out long ago, the addressee of this poem and the recipient of the secret letters written in the special clavis must have been the Polish palatine's wife, a major politician of the times, Rákóczi's love, Elżbieta Helena Sieniawska $(1669-1729) \cdot{ }^{8 \circ}$ It is worth noting that Rákóczi

79 On Rákóczi's knowledge in French: Ilona Kovács, "Exil et Littérature: La période 1711-1735 dans l'oeuvre de François II Rákóczi," Cahiers d'études hongroises 7 (1995): 20-28.

80 The authorship and addressee of the poem was identified by Árpád Markó: “A versíró Rákóczi" (The poet Rákóczi), Magyar Könyvszemle 26 (1936): 259-264. 
usually wrote his letters to Sieniawska in French, ${ }^{81}$ while he used German in his letters to his wife, with whom he also had a separate homophonic clavis, just as developed technically as the previous one, lacking, however, such emotionally loaded words. ${ }^{82}$ Consequently, this second French clavis must have been used to protect the prince's intimacy, and not to help his diplomatic correspondence.

The next example is related to the relatively unknown historical actor, István Dalmády, and Mihály Teleki, his often quoted childhood friend, then would be Transylvanian politician. Dalmady's letters to Teleki, concealed another type of intimate relationship. A recurrent theme in these is that Dalmády assures his friend of his devotedness, and urges the twenty-oddyear-old Teleki to meet him. He even asks for a clavis in an early letter in 1659. "The synceritas you show towards me is a reality for me. I ask you to judge me similarly." And in the same letter, he goes, "If it is not inconvenient, please make a clavis of secret letters, so we could write to each other with bigger confidentia. But I am asking you to try and arrange a meeting as soon as possible, so we could meet in person. You are a very fast young lad, you could find a good way to get here, something that I would like very much, and you would not regret either." ${ }^{83}$

Then, already owning and frequently using the clavis, he repeatedly emphasizes the sincerity, specialness and stability of their relationship, all the while urging a personal meeting, "Believe me, I am assured about your true affectio towards me, that I have no other friend in this whole world like you." ${ }^{84}$ (The enciphered words are marked in italics.) "There is nothing I would not do foryou, and if you doubt it, I will give you a reversalis about it." "85 "Trust me, I am yours. I have no other, more secret and truer friend in the whole world, than you." 86 "For I think of You and love you as myself. May God help us talk to each other as soon as possible." ${ }^{87}$

In these times there was nothing unusual about expressing such a high level of respect, faithfulness or friendship in personal letters. Yet the way Dalmády is devoted and the way he expressed it, are both extraordinary. He must have known that this is not becoming to male friends, so he used

81 Gábor Tüskés, Ilona Kovács, Béla Köpeczi, eds. Correspondance de François II Rákóczi et de la palatine Elżbieta Sieniawska 1704-1727 (Budapest: Balassi, 2004).

82 Ráday Archives C64-4d2-25. 5. On the back of the table: Mme la Comtesse de Transylvanie.

83 Teleki 1, 311-312, 278.

84 Teleki 1, 320, 284 .

85 Teleki 1, 336, 298 .

86 Teleki 1, 350, 310 .

87 Teleki 1, 386. 340. 
ciphering (see in italics) every time he was writing about his emotions. His open letters or the parts that are left open, are considerably more restrained. This relationship must have looked strange in the eyes of the people surrounding them too, at least that is the way it sounds from the following quote, "I wish I could talk to you soon, I would truly pour out all my heart, my secrets to you. I wish to be face to face with you, twice as strongly as before (...) If I need to, I will keep secret any of the things you entrusted me with; I will take Your covenant with me to my coffin. I will regret that many know our true friendship, because both of us have many people who envy us." ${ }^{\prime 88}$

In the following, he gets more enthusiastic, stressing his devotedness even more, all the time enciphering the emotionally loaded words, "Truly, since I have not seen you, not one day has passed that I have not thought of you." "I "I will confess to you that I have no better friend than you." ${ }^{\text {"o }}$ At times he literally confesses his love to Teleki, "I am writing this to you with a good conscience, my soul has not been drawn to anyone than you; be sure about it, I have no truer friend in this world than You. ${ }^{\text {gil }}$ As a true friend, he also gives him marriage advice, ${ }^{92}$ and later comforts him on losing his wife, "but, my sweet lord, what can you do about it? she will not be raised from the dead (...) The Lord God gave her and the Lord God took her away."93

Then he considers his friend's marriage again, while emphasizing over and over again how much he misses his friend, evaluating their friendship, and then finally concluding by using the word amanti to describe themselves. "It is to my contentio that you have been assured about my perfect and sincere friendship to you. You are right, we should not trust every friendship. I have also been assured about you so much, may the Lord God bless me, I regard you highly above all other friends (...) it has been 17 full months since we have seen each other, I wish I had at least two hours to talk to you. I am already thinking about your marriage. I would be ready to assist you in love with all my talent, if I had the means. (...) My dear sweet brother, there should not be any problem between the two of us. Amanti enim nihil difficile. Still, I am begging you, let us make plans to meet each other as soon as possible, this would do both of us good."94

\footnotetext{
88 Teleki 1, 395-396, 346.

89 Teleki 1, 474-475, 410.

90 Teleki 1, 507-508, 433 .

91 Teleki 1, 496-498, 426.

92 E.g. Teleki 1, 372-374, 331.

93 Teleki 1, 500-502, 428.

94 Teleki 1, 500-502, 428.
} 
Teleki's answers are not known. He does sometimes mention Dalmády in letters written to others, but always in connection with some practical matter. What is known about Teleki is again from one of Dalmády's letters, namely, that he had dreamed about Dalmády once, "Your dream about me, my dear brother, is not in vain. ${ }^{95}$ It is not known exactly how the meeting went, when they finally met, to the joy of Dalmády. His enthusiasm, however, somewhat abates in the coming years, or they may have agreed that their relationship is only a friendship after all. Dalmády, for sure, writes less in a clavis, and there are no more expressions of love like the ones quoted above.

What is common in the enciphered correspondences of Anna of Austria and Mazarin, Rákóczi and Sieniawska, or Dalmády and Teleki is that the encrypted content is personal relationship, love, devotion, desiring each other's company and friendship.

\subsection{Family secrets and privacy: ladies and ciphers}

Dalmády has an - almost completely enciphered - postscript after one of his letters, which is entirely devoted to supporting the then twenty-fiveyear-old Mihály Teleki in his marriage plans, "You might be asking my advice about an already arranged thing, because I have already heard from others about your plans to marry the young girl. I have heard good about the family of poor old Ferenc Pekri, I have also known him personally, but I do not know how wealthy he is, if he has any wealth at all. The girl loves you, you like her too, so I advise you to marry her, just be careful about the means, because I do not know where else you could find it. The princes are not very generous in handing out the gratia, even that Barcsai, You will see it now. For God's sake, do not tie yourself to him together with your marriage, because God's blessing will not rest on you; You might risk Your good reputation, name and consciencia. For me, the only hard thing that I often think of will be that our true friendship will get cooler in your absence. ${ }^{n 6}$

The few enciphered sentences of the famous Hungarian poet, Bálint Balassi (1554-1594) also belong to the chapter on encrypted family secrets. The castellan, poet, soldier and great seducer lived in a never-ending inheritance dispute with his relatives. A number of towns were pursuing him in discipline issues because of his scandalous and pugnacious nature. He had 
an endless number of love affairs to add to his problems. During his rough and tough life he was often forced to use encryption in private and financial letters too. ${ }^{97}$ He used partial encryption, only enciphering certain names, most often names of people..$^{8}$ He had a monoalphabetic code, a very simm ple one. He assigned the first half of the alphabet to the second half, and vice versa. Once he enciphered his request to keep something secret in this way, "But if you are my lord and true friend, bq zcqucb [do not tell] gqbxubqx gqauh [anyone a word]".99

It is hard to figure out whom Balassi wanted to confuse with this simple method, but after all, the best codebreakers of the Habsburg court were not likely to be interested in his heritage and love secrets, and this method could have successfully protected his letters from nosy mailmen, or relatives. He wrote altogether four letters, where the encrypted text portions mainly to conceal his marriage plans. In one famous line, "I will be a great lord, if all else fails, by means of my cock," he refers to his plans to get rich by marrying. It reads like this, "bmsu if yqzqx, if all else fails, rmfxma ihmb."100

Women and family matters only serve in these letters as the topic of the encrypted parts. There are other cases, however, in which the corresponding partners are women: wives, relatives, female politicians. A study of the sources clearly reveals that enciphering in early modern Hungary was not a male privilege.

It was not even a male privilege in the late medieval times either. Beatrix of Aragon (1457-1508), wife of King Matthias Corvinus (1443-149o), corresponded with several Italian political figures, but she only used encrypting with a few partners. One of these was her sister, the princess of Ferrara, Eleanor of Aragon. The sisters used a simple monoalphabetic cipher with graphic signs. Their letters are kept in the State Archives of Modena, ${ }^{101}$ inn cluding the one in which Beatrix is sending Eleanor the code key. ${ }^{102}$

97 Kőszeghy Péter, Balassi Bálint, Magyar Alkibiadész (Balint Balassi, the Hungarian Alcibiades) (Budapest: Balassi, 2008).

98 Révay, Titkosírások, 69-73; Sándor Eckhardt, Balassi Bálint összes müvei (Complete Oeuvre of Bálint Balassi) (Budapest: Akadémiai Kiadó, 1951); Béla Stoll, ed. Balassi Bálint, Összes versei (All the poems of Bálint Balassi) (Budapest: Helikon, 1974) 26o-264, no. 5; 264-267, no. 6.; 269-271, no. 8; 391-394, no. 87 .

99 Stoll, Balassi, 394.

100 Stoll, Balassi, 394.

101 MNL OL Microfilm Reading Room Mf. 8620.

102 Nagy Iván and B. Nyáry Albert, eds. Magyar diplomácziai emlékek Mátyás király korából 1458-1490. (Hungarian diplomatic sources from the time of King Matthias, 1458-1490) vol. III. (Budapest, 1877.), 67: "Con la cyfra havemo antiquamente con Yostra Signoria con la quale la fara cavare, et accioche cla qua avante Yostra Signoria et suo consorte possa serivere ala Maesta de nostro marito et ad nuj, ne li mandamo qui alligata un altra nova, con la quale le Signorie Yostre 
There are several examples when secret letters are exchanged with one's wife. One private letter sent by the count István Illésházy (1541-16o9) from his temporary exile to his wife, Katalin Pálffy in 1605 is an easy-to-break cipher where only the vowels are coded, although this was not actually identified until very recently. ${ }^{103}$ A stronger code was used by the count Sándor Károlyi to his wife, Krisztina Barkóczy ${ }^{104}$ in one still unbroken line of a 1706 letter, and Mihály Teleki and his wife both used encryption in writing to each other in the military turmoil of those years, though mostly in the postscripts. In these encrypted sections politics mingles with marital affection and worrying about each other. This is what Teleki wrote to his wife "Sweetheart, there will be enough Germans coming, do not worry, God will provide." ${ }^{105}$ In her already quoted response she answers: "If you had left long ago this place, you would have been captured by the gunmen." ${ }^{106}$ She writes to him a few days later again in an encrypted postscript, "Mihály Katona is your friend, but the courtjudge is evil. Lord Mihály Katona has quarreled a lot about some wretched cattle that, but I did not get involved." ${ }^{107}$ Teleki, by the way, also tried ciphered correspondence with Mária Széchy, the wife of the palatine ${ }^{108}$ but neither her, nor us could decode what he had enciphered. ${ }^{109}$

\subsection{Private sins - public morals: secrets of a diary and shame}

Having read the previous sources, one can reach some noteworthy conclusions. The nature of the enciphered content changes along with the genre of the encrypted literature and the social category the author belongs to. In the latter sources, the covered information falls more in the category of privacy, rather than secrecy. It is even more typical of the genre of diary.

Early modern Hungarian history is rich in diaries. ${ }^{100}$ Only a small porf tion of diary writers used encryption, and they enciphered only a limited

potrano serivere, che cossi fara nostro marito, et nuj ancora con essa medesimo seriveremo ad Yostra Ill-ma Signoria, ala quale le ce recommandamo, et si dignara Yostra Signoria da parte nostra basarerre tutti soi Ill-mi figlioli, li quali tutti salutamo."

103 Vadai, "Két XVII. századi titkosírás megfejtése."

104 MNL OL P. 398, The archives of the Károlyi family, the age of Rákóczi: no. 35409.

105 Teleki 2, 293-294, 220.

106 Teleki 2, 294-295, 223.

107 Teleki 2, 304-305, 229 .

108 Teleki $3,582-583,432$.

109 ibid., 593, appendix to letter 441.

110 Margit S. Sárdi, Napló-könyv: magyar nyelvü naplók 1800 elött (Diary-book: diaries in Hungarian before 1800) (Budapest: Attraktor, 2014). 
amount of their text. Their cryptographic practice and concept of secrecy is rather fascinating, nevertheless. In the following we are going to introduce writers whose political roles differ significantly, but whose encrypting practices are fairly similar.

The whereabouts of the manuscript of Gábor Haller's (1614-1663) diary written between 1630 and 1644 is unfortunately still not known, so it is only available in a source publication from a hundred and fifty years ago. ${ }^{\text {II }}$ Haller was a major political figure in his times in Transylvania. As a teenager, he was the valet of Catherine of Brandenburg, princess of Transylvania and then of György I. Rákóczi, then he traveled, and studied military engineering and mathematics in Leiden. Later he worked for several subsequent Transylvanian princes, the third of whom lured him over to his service, and finally he headed the legation sent to the Turks in Timisoara, where he was captured and executed, as politics changed back in Transylvania. ${ }^{112}$ His papers go missing then, but the already complete diary he had left home survived him - to disappear only later.

As many as twenty-two short sections are enciphered in this diary. Haller used two different methods. The first is a simple anagram that he explains in detail at the end of his diary, in case the reader failed to break it on his own. ${ }^{113}$ The second is a version of the famous pigpen cipher, made up of a grid and dots, later also used by the Freemasons. This cipher appears to be graphic, but is indeed monoalphabetic and its logical setup (of an alphabet placed in a grid) makes it easy to decode even for those who are not familiar with this method.

Surprisingly, Haller, who studied mathematics in the West, and (could have) had access to the most up-to-date ciphers of his time, chose such a childish way of encryption. After all, he played a major role in the politics of Transylvania, facing constant threats in trying to make his way around four princes. One explanation could be that cryptologic knowledge was not transferred to Central Europe by means of Western cryptographic and mathematical handbooks, rather by diplomatic practice and personal contacts. If Haller had no major source with which to compare his ciphers other than the diplomacy of his own time and country, it is no surprise that he

111 Gábor Haller, Napló, 1630-1644 (Diary, 1630-1644), in Károly, Szabó, ed. Erdélyi Történelmi Adatok, 4 (Kolozsvár: Erdélyi Múzeum Egyesület, 1862): 1-103.

112 András Péter Szabó, Haller Gábor - egy 17. századi erdélyi arisztokrata életpályája, (Gábor Haller, the career of a Transylvanian aristocrat) Doctoral dissertation, ELTE, http://doktori.btk. elte.hu/hist/szaboandras/diss.pdf last accessed: 2017.07.29.

113 Haller, Napló, 103. 
stayed on the level of pigpen ciphers. Not even his lord, György Rákóczi I had used a better cipher with his own envoys.

There is another explanation for the simplistic ciphers he had used: he might simply have regarded encrypting as a playful activity. He seems to invite his readers for a game. He does not seem to mind that his reader finds a way to the encrypted parts too, that is exactly why he gives the key at the end of the diary. ${ }^{114}$ In either way, nineteen of the twenty-two encrypted senn tences can be found in the pre-1637 part of the diary, the times when Haller was not yet a significant figure in politics. He could, after all, have decided simply not to write down his truly important political secrets.

But what did he actually write down in cipher? Small secrets of politics, and details of various negotiations. More frequently, however, family issues (marriage plans the prince had for him), ${ }^{115}$ remarks on his own feelings, and his struggle with alcohol. "I was drunk and behaved in a way I should not have." He makes a resolution, "I promised not to drink wine for a month." Two days later, "This is how long I could go without wine." Next he records on a two-day period, "Drunk, feeling sick."116 He encrypts his record on how the prince had sarcastically noted that he would sooner find a cup of wine than a book. Once he covers up a dream in which he is punished for his sexual desires, "In my dream I saw Moses come down from heaven to grab me and threaten me for my sins, at which I got scared and prayed to God and immediately stopped having sinful desires. ${ }^{117}$ He may have had other ciphered comm ments with a sexual topic because the bashful editor decides to leave out two ciphered parts, a behavior that is not quite worthy of a philologist. ${ }^{118}$ All in all, the secret to be enciphered for Haller is related to his private life.

Zsigmond Szaniszlós (c. 1655 - c. 1721) enciphered diary records served similar purposes of hiding details of private life and personal secrets. ${ }^{119}$ Szaa niszló, a notary and later high judge of Torda County in Transylvania, made a record on almost every single day of the period between 1682 and 1711, making his diary a truthful, if somewhat monotonous summary of his life.

"November

5: Gave the belt maker denar 6o for rice porridge and linen.

114 See also the conclusion of Sárdi, Napló-könyv and Szabó, Haller (174).

115 Haller, Napló, 30.

116 Haller, Napló, 16, 25, 69.

117 Haller, Napló, 38.

118 Haller, Napló, 31, 44.

119 Zsigmond Szaniszló, Napló, 1682-1711 (Diary 1682-1711), ed. Károly Torma, Történelmi Tár 1889

(12). 230-269, 503-522, 708-727, (13), 1890. 77-101, 307-327, 493-510, 757-770, (14), 1891. 267-295. 
8. Sent Michael to Komjáczeg with the wagon. He brought the oat approx. metr. 61, also brought cabbage a(bout) two hundred.

11. Martin came on a white horse. I went to Komjáczeg.

13. I herded cattle from Polyan. Mss Miklós has brought some pots..."12o

When he wished to hide something, he used a very simple transposition cipher but certain letters (f, h, k, l, z) are left unchanged. ${ }^{121}$ The ciphered parts, usually only single words, are connected to the accounts ("I have bought hay for 56 fl.") to family (his daughter's marital problems), or unchaste acts ("I have caught John Váradi with a woman last night"). Some other records do also report a lewd act, but without encrypting ("I have had a prostitute tied up in that same place.") and he leaves a few curses as open texts too ("that motherfucker"). ${ }^{122}$

The most appalling encrypted record of the diary reveals an amoral event connected to his family life. His wife, heavily pregnant with their daughter who is to be born 8 July, spends the night of 30 April 1693 in the company of their established guest, "I have understood that the treasurer had spent the night with my wife. Dear Lord, do not forsake me, for the sake of your holy son, help me! I could not help it." ${ }^{123}$

All of these details are only slightly better hidden than the secrets in Haller's diary, who directly provided the key to the code he had used. Szaniszló obviously did not expect determined codebreakers to work on his diary that he had always carried with himself. More likely he was only trying to defend the financial secrets and intimate details of his diary from people casually peeking into it. The dreams and alcoholism of Haller, the adventure of Szaniszló's wife, or even the vulgar comment of Balassi on his plan to get rich - all of these are cases that Georg Simmel's above quoted observation seems to apply to: secrecy is often not simply a hidden piece of information, but more like the mark of shame, the documentation of trespassing the boundaries of social norms

Not all enciphered diary records are connected to privacy, however. There is an entire chapter of early modern Hungarian diaries that are different: the daily records of envoys, the aim of which was to record data to be used later in an official report. Both Thököly and Rákóczi ordered their envoys to make detailed diary-like entries of delegations, Thököly even adding the use of clavis. ${ }^{124}$ Thus, envoys produced lengthy diaries, and some

120 Szaniszló, Napló, 247.

121 Encrypted parts: 1889 : 505, 506, 518, 715, 718; 1890: 85-86, 88; 1891: 290.

122 Ibid. 1891: 518, 505, 84, 270.

123 Szaniszló Napló, 189o: 85-86.

124 Benda, Pápai János törökországi naplói; Thaly, Késmárki Thököly Imre, 614. 
among them used encryption. ${ }^{125}$ These diaries are official documents, comm ments about personal life are missing from the enciphered parts of them, the occasionally encrypted paragraphs cover rather the confidential details of their negotiations.

\subsection{Science, chemistry and alchemy}

Despite the fact that science is conventionally regarded as a public affair, there are long-standing traditions of encrypting scientific results. ${ }^{126}$ One of the earliest and perhaps most publicized cases are the anagrams Galileo Galilei sent to the envoy of Prague in Florence (and indirectly to Kepler). The first message (smaismrmilmepoetaleumibunenugttauiras) preceded the 1610 appearance of Sidereus Nuncius, and documented the discovery of the moons of Saturn: Altissimum planetam tergeminum observavi (I have observed that the uppermost planet is a triplicity). The Florentine scientist acted in a similar way when announcing the moonlike that is, phasehaving) behavior of Venus. But for the last two letters, this anagram was meaningful on its own: Haec immatura a me iam frustra leguntur - oy (these immature things are yet read by me in vain - o y). Its other form, using all the letters, Cynthiae figuras aemulatur mater amorum, (the Mother of Loves [Venus] imitates the forms of Cynthia [the moon]), documented Galileo's real discovery. ${ }^{127}$

Sixty years later similar anagrams were sent by the first scientists of the Royal Society, Christian Huygens, Robert Hooke, and even Isaac Newton to the Society's secretary, Henry Oldenburg, about discoveries that they had not had the opportunity to confirm, or simply had not published yet. ${ }^{128}$

125 Diary of Mihály Bay naplója: MNL OL G. 15. Caps A.1. Fasc 24. fol. 75- 124r. Diary of Gáspár Sándor: MNL OL G. 15. Caps A.1. Fasc 24. fol. 1-28. Published: Kálmán Thaly, ed., Késmárki Thököly Imre, Bay: 579-627, 646-65o. Sándor: 651-708.

126 Ernan McMullin, "Openness and secrecy in science: some notes on early history," Science, Technology and Human Values 10 (1985): 14-23. David Hull, "Openness and secrecy in science: their origins and limitationism," Science, Technology and Human Values 10 (1985):4-13;

127 Mario Biagioli, Galileo's Instruments of Credit:Telescopes, Images, Secrecy, Chicago: University Of Chicago Press, 2006); idem, "From ciphers to confidentiality: Secrecy, Opennes and Priority in Science," The British Journal for the History of Science, 45 (2012): 213-233.

128 Thomas Birch, The History of the Royal Society of London for Improving of Natural Knowledge, From its First Rise (London: Printed for A. Millar in the Strand 1756-57) Vol.2, 345-345, and vol. 3, 179 and 190. See also: Kristie Macrakis, "Confessing secrets: secret communication and the origins of modern science," Intelligence and National Security 25 (2010): 183-197. Biagioli, "From ciphers to confidentiality," Gábor Zemplén, "Newton's Strategic Manoeuvring with Simple Colours and 
Nevertheless, anagrams are not ciphers. They are not based on the substitution of letters, but on their transposition. The most important difference is that anagrams often have several solutions. This is why Kepler could solve Galileo's first anagram in a completely different way, making sense of it in light of his own Mars-related theory. Anagrams cannot be broken as a cipher, and they are not meant to be channels of secret communication. The goal of these scientists was to document their own scientific hypotheses and the priority of their discovery in an age when the mechanisms of establishing priority were not yet established. There existed patent office-like institutions, and publishing a discovery in a book or journal was also an available alternative, but a particular scientist never knew where the system leaked - which editor, patent specialist or assessor of a contest would pass on crucial information. We now know that the very idea of Galilei's telescope was also the result of such a leaking, ${ }^{129}$ so we are not surprised that Tycho Brahe felt the need to have his own press operating on the island of Hven, the place of his astronomical discoveries. The process of printing a discovery, which meant to secure its priority, involved risking its very priority. The use of anagrams did not aim at disguising, it was rather meant to provide protection from the risks inherent in the process of recognition and publication. It was a defense mechanism. ${ }^{1{ }^{\circ}}$

The motivations of the astronomer Michael Van Langren might have been similar to those of Tycho Brahe, when he published a small book in 1644 in Spanish, with the title La verdadera Longitud por mar y tierra. The book puts forward a solution to one of the most urgent scientific problems of the age, the exact determination of longitude. This had become a burning issue in navigation: based on the position of the Sun and the stars, it was relatively easy to determine the latitude of the position of one's ship in the open ocean, but for exactly determining the longitude (and thus, answering questions such as "How far is America from here?" or "Where do the continental shelves begin under the water?"), they would have needed more precise chronometers than were available at the time. Sovereigns recognized the importance of the problem, and founded grants to encourage scientists to solve it. Van Langren finally found the solution. However, we

Diagrams: a Radical Historical Interpretation," in Tamás Demeter, Kathryn Murphy and Claus Zittel, eds. Conflicting Values of Inquiry: Ideologies of Epistemology in Early Modern Europe (Leiden: Brill, 2014): 221-245.

129 Mario Biagioli, "Venetian tech-transfer: how Galileo copied the telescope," in Albert van Helden, Sven Dupré, Rob van Gent and Huib Zuidervaart, eds., The Origins of the Telescope (Amsterdam: Amsterdam University Press, 2011): 203-230.

130 Biagioli, "From ciphers to confedentiality." 
are not in the position to assess whether he was right or not, because he enciphered his proposition before he printed it, and this cipher text - not longer than a paragraph - still resists code breakers. The first solution that we can actually read was proposed a hundred years later, when, in the mid-eighteenth century, John Harrison developed such precise clocks that the determination of longitude on open sea finally became possible..$^{1{ }^{1}}$

Proper ciphers - that were not used to ensure priority, but rather concealed a longer text and could be actually solved - were used only to a limited extent in scientific and technological texts. A well-known case is that of the Renaissance engineer Giovanni Fontana (c.1395?-1455). Fontana used substitution ciphers in entire books, among them his Bellicorum Instrumentorum Liber, describing his complex military machinery, and his Secretum de Thesauro, on mnemotechnic devices. He used simple, monoalphabetic substitution ciphers. ${ }^{132}$ What his motivations might have been we can only guess, but we are probably not very far from the solution if we suppose that he wished to add to the secrecy of the description of the technological devices as well as demonstrating how his substitution cipher itself functioned. As cracking Fontana's code was not hard, one could more properly call this procedure the rhetoric of secrecy than a real secretive technique.

The motivations of Robert Boyle were different. He relied more heavily on proper cryptographic methods, such as name substitution, code words, and monoalphabetic ciphers. He applied these in his private letters, not his published documents. The purpose of his secrecy was different from that of Huygens, Hooke, and Newton. It was not to secure the priority of a discovery; rather, he did not wish the results of his alchemical experiments to be found out. No professional codebreakers would have been stopped by his encryption, however. His purpose was, instead, to exclude his learned assistants from the communication of his secrets. ${ }^{133}$

131 Valero-Mora and Ibáñez Ulargui, "The First (Known Statistical Graph: Michael Florent van Langren and the 'Secret' of Longitude," 2010. http://www.datavis.ca/papers/langren-TASog154.pdf (accessed July 27, 2017)

132 Lynn Thorndike, History of Magic and Experimental Science (New York: Columbia University Press, 1923-58), vol 4. 150-182; Alexander Birkenmajer, "Zur Lebensgeschichte und wissenschaftlichen Tätigkeit von Giovanni Fontana (1395?-1455?)" Isis 17 (1932): 34-54. Bellicorum Instrumentorum Liber (München, Bayerische Staatsbibiliothek, Cod. Icon. 242), Secretum de thesauro experimentorum ymaginationis hominum (Párizs, Bibliotheque Nationale, Cod. Lat. Nouv. Acq. 635). See also: Horst Kranz, Walter Oberschelp, eds., Mechanisches Memorieren und Chiffrieren um 1430: Johannes Fontanas Tractatus de instrumentis artis memorie (Stuttgart: Steinr, 2009).

133 Lawrence M. Principe, "Robert Boyle's Alchemical Secrecy: Codes, Ciphers and Concealments," Ambix, 39 (1992): 63-74. 
Another completely enciphered book, which forms an entirely independent category, is the world-famous Voynich manuscript. ${ }^{134}$ This book, with its unique drawings of biology, astronomy and bathing women, plus a writing system that is completely confusing, has kept myriads of codebreakers, information technologists and historians enthralled ever since a Polish antiquarian and bookdealer, Wilfrid Michael Voynich (1865-1930), had bought it in the 1910s from the Jesuits in Villa Mondragone, Italy. The book has created a whole subculture of codebreakers who have conferences and communicate via an email list. Apart from the groups of amateurs, a number of special historians and philologists have examined it, and the best cryptographers of WWII had tried to identify its code in vain, even William Friedman (1891-1969), ${ }^{135}$ who had broken dozens of Japanese mill itary codes. The illustrations help to distinguish three longer sections, one on astronomy, one on balneology, and one on botanics, but the script next to the pictures remain illegible. It is not even known whether the writing is a cipher text, a code, a constructed or an existing language.

One naturally has the lurking suspicion that the book is either a hoax or a counterfeit document. Several people have been suspected of having forged the codex, from the sixteenth-century medium and alchemist Edward Kelly to the twentieth-century collector, Wilfrid Voynich. Their motivation is thought to have been nothing else than to create a mystical and enthralling book that would sell for a fortune. This could have been the case with Kelly, whose main sources of income were the gullible John Dee, English mathematician and magus, and the generous Rudolf II, Holy Roman Emperor; but also with Voynich, who made a living by selling books to enthusiastic readers. Along with these historical arguments, the hoax hypothesis was also thought to be supported by statistical data based on the characteristics of the text. ${ }^{136} \mathrm{~A}$ recent American laboratory study, nonetheless, revealed the pages to be from the fifteenth century, so the modern hoax theories seem to be ruled out. ${ }^{137}$

134 Two titles and three webpages from the rich bibliography: Mary E. D'Imperio, The Voynich Manuscript - An Elegant Enigma (Aegean Park Press, 1978); Gerry Kennedy, Rob Churchill, The Voynich Manuscript (London: Orion, 2004); http://www.voynich.nu/, http://www.world-mysteries. com/sar_13.htm, www.ciphermysteries.com.

135 Jim Reeds, "William F. Friedman's Transcription of the Voynich Manuscript" Cryptologia 19 (1995): 1-22.

136 Gordon Rugg, “An Elegant Hoax?”; Andreas Schinner, “The Voynich Manuscript: Evidence of the Hoax Hypothesis" Cryptologia $3^{1}$ (2007): 95-107. See also: Gabriel Landini, "Evidence of Linguistic Structure in the Voynich Manuscript Using Spectral Analysis" Cryptologia 25 (2001): 275-295.

137 Paula Zyats, Erin Mysak, Jens Stenger, Marie-France Lemay, Anikó Bezur, and David D. Driscoll, "Physical Findings" in Raymond Clemens, ed. The Voynich Manuscript. New 
Obviously, we cannot completely dismiss them until the code is broken. It is still not satisfactorily verified whether the manuscript is really an enciphered scientific work, or an example for an artificial language, or just some automatic writing.

In the old secrecy-openness dichotomy, alchemy was certainly on the secretive side, considered to rely on all kinds of methods that excluded uninvited readers from alchemical communications. In recent decades, however, historians have increasingly noticed that secrecy in alchemy is a more complex issue; in fact it was not in all cases more secretive than other occupations of the period. ${ }^{1{ }^{8}}$ To be sure, metals were represented by special graphic symbols, and many alchemic documents combine symbolic language use with chemistry. However, direct and intentional encryption, as seen in Boyle's letters, was rare; in any event only a few ciphers applied in alchemical texts from before 1600 are known. One of them is from the Beinecke library (just like the Voynich manuscript), the sixteenth-century Latin and German collection of alchemical (and partly medical) recipes of a certain Martin Roesel of Rosenthal from around 1586, in which some recipes are encrypted in a numeric monoalphabetic cipher. ${ }^{139}$ Another one is from the national library of Madrid, the Libro del Tesoro attributed to Alfonso the Wise, a twenty-page text, which is almost entirely encrypted..$^{140}$ Both manuscripts have been identified and researched by the historian of alchemy Agnieszka Rec, who argues that the relative lack of cryptography in sixteenth century alchemy is due to the fact that the kind of secrecy guaranteed by ciphers do not actually fit the special needs of the alchemists. In fact, she writes: "ciphers represent an entirely different tool than that commonly wielded in the service of alchemical secrecy. Other methods alchemists relied on to conceal their ideas - Decknamen, allegories, and others - were meant to exclude the great mass of the unworthy, but they were by design legible to those with the appropriate knowledge, that is,

Haven and London: Bienecke Tate Book \& Manuscript Library and Yale University Press, 2016, 23-37.

138 The traditional view contrasting secretive alchemy with open chemistry or public mining methods: Betty Jo Teeter Dobbs, "From the secrecy of alchemy to the openness of chemistry," in Tore Frängsmyr, ed., Solomon's House Revisited, (Canton: Science History Publications, 1990): 75-94; Long, Openness, Secrecy, Authorship. The criticism and reappraisal of this view: William Newman, "Alchemical symbolism and concealment," in Peter Galison and Emily Thompson, eds., The Architecture of Science (Cambridge, MA: MIT Press, 2000): 59-77; Tara Nummedal, Alchemy and Authority in the Holy Roman Empire (Chicago: The Chicago University Press, 2007).

139 MS Beinecke Mellon MS 27 (fol. 23r). Agnieszka Rec, "Ciphers and Secrecy Among the Alchemists: A Preliminary Report," Societas Magica Newsletter, 31 (2014): 1-6.

140 Madrid, Biblioteca Nacional, MS reservado 20. 
other adepts. When a text instructed the alchemist to "take the green lion" (recipe leonem viridem), he would know to reach for his supply of antimony ore. Ciphers present an entirely different barrier to entry. Revealing their contents does not require a particular body of knowledge, but rather a single piece of information: the cipher key whether obtained directly or figured out. Any reader can recover the text if he can get the key. Acquiring that key becomes much easier when an earlier reader writes in the solution next to the cipher (....) With ciphers, then, being worthy is entirely beside the point, and the alchemist very quickly loses control of his readership. It is precisely this quality that makes ciphers uncommon in alchemical manuscripts, which, as books of secrets, were meant to be written in a particular language understood by a chosen group."141

A third, in many ways similar source survived from the region of Hungary, that is the diary of Johannes Cementes of Kolozsvarr, a sixteenth-century jewelry maker who worked in the mint of Cluj (then part of Hungary: Kolozsvár) as a "cement guy": a refiner of precious metals. His diary, from the mid- $16^{\text {th }}$ century, consists of almost two hundred pages, and is basically a collection of recipes, including jewelry-making, gold refining and alchemy, written partly in Latin, partly in Hungarian. ${ }^{142}$ The diary is entitled The Book of Happiness. More precisely, the title is "The name of this book is happiness, if you live with it the way I do," and the very title itself is enciphered. The author provides the code key right at the beginning on fol. $2 \mathrm{v}$, which enables those few sentences that are encrypted to be read. Just as the two previous alchemical texts, this diary also uses a simple monoalphabetic method; as such, none of them constitute the highest achievement of cryptography available in their period:

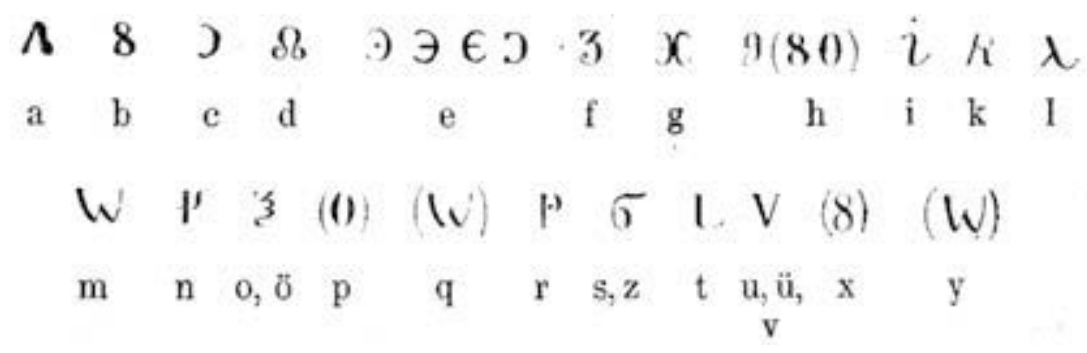

The Cipher-key of János Cementes ${ }^{143}$

141 Rec, "Ciphers and Secrecy," 4-5.

142 I thank Dóra Bobory for calling my attention to this source. Herzfelder Armand Dezső, "Kolozsvári Czementes János könyve" (The book by Johannes Cementes of Kolozsvár) Magyar Könyvszemle (1896): 276-301, 351-373; Zolnai Gyula, "Jegyzetek Czementes János könyvéhez" (Notes to the book by Johannes Cementes), Magyar Könyvszemle (1896): 373-377.

143 Herzfelder, "Kolozsvári” 277. 
Cementes often represents the metals with their alchemical symbols in the mining, minting and alchemic recipes, and occasionally he enciphers a few words in describing a procedure, like the use of the candle applied in treasure hunts:

"Candela bona, cum qua thesaurus inveniatur.

Rp. ceram virgineam three parts with four part camphor and with five part myrrh and six part sulphurusstone et mercurium sublimatum, quibus mixtis iterum adde seven part sulphurusstone. Deinde virgo... litman de lana alba that is wool ad longitudinem unius cubilis et perficias candelam illam, incende et ardebit quiete et ubi faerit thesaurus, mox extinquitur. Super quod adducta faerit sive in terra, sive in muro vel pariete."

In his practices of secrecy, Cementes did not distinguish between recipes of alchemy and treasure hunt, on the one hand, and jewel-making and gold refining descriptions, on the other. He did not encrypt consequently the first category and left as plain text the second. For example, his unencrypted recipes include many that are similar in nature to the one quoted above. Alchemy and gold refining for Cementes fall in the same category from the point of view of secrecy.

\subsection{Secret characters and magic}

Magic, just like alchemy, had been represented in the traditional literature as secretive in contrast to science, which was supposed to be open. ${ }^{144}$ Howw ever, as we have seen in the introductory chapters, this simplifying opposition has, fortunately, been lately modified ${ }^{145}$ Still, and most interestingly, learned magic and cryptography seem to have had an unusually close relationship in the sixteenth and seventeenth centuries. They share their major authors, to start with. Works of Cornelius Agrippa and John Dee contain secret alphabets, whereas Johannes Trithemius, Athanasius Kircher, and Gerolamo Cardano were all authors noted in both the history of magic and the history of cryptography.

In late medieval magical manuscripts, written or compiled by anonymous authors, accessible and popular in circles of students and the low clergy, cipher alphabets and shorter encrypted messages appear in considerable quantity. Some of these alphabets and messages were the inventions

144 Brian Vickers, ed., Occult and Scientific Mentalities in the Renaissance (Cambridge: Cambridge University Press, 1984).

145 Vermeir, “Opennes versus secrecy." 
of the scribes, others appeared in such widespread and often copied texts as the Picatrix, the Book of Runes, and a number of short hermetic and Salomonic texts. ${ }^{146}$ In the Book of Runes for example - a Latin talismanic text on manipulating planetary spirits - the spirits' names are to be engraved on metal plates in a runic alphabet associating the sacred aspect of the runes with the celestial forces. This was the most famous, but not the only, magical text featuring a runic script. In a German manuscript from the late fifteenth century, for example, runic characters were used for transcribing various names and notions of the divinatory, prognostic, and occasionally demonic material of the book. In a demonic invocation written in proper German, for example, the following terms are spelled in runes: boes geist (malign spirit), diabolo diaboliczno, satana sataniczno, and kum her zuo mir (come to me). ${ }^{147}$

Cipher alphabets in magical texts have two common traits. First of all, they all stay on a relatively simple level, not stepping beyond the usual monoalphabetic system, despite the fact that by this time, the turn of the fifteenth and the sixteenth century, homophonic systems complemented with nomenclatures were known. Furthermore, ciphers in magic manuscripts usually encrypt short fragments of texts, and more often than not, these text fragments function as names of planetary spirits, as characters to be inscribed in a planetary talisman used for benign and evil magical purposes, or simply as demonic invocations. ${ }^{148}$

Proceeding in time, and looking at early modern manuscripts of magic, the picture does not change substantially. The wide range of magic alphabets collected in the comprehensive book by Gilles le Pape (Les écritures magiques) are again without exception monoalphabetic, be they of Arabic, Hebraic, Irish, or Western European origin. Cornelius Agrippa's celestial alphabets, the many anonymous talismanic ciphers, and even the famous Freemason cipher belong to this simple category. ${ }^{149}$

146 Benedek Láng, Unlocked Books, Manuscripts of Learned Magic in the Medieval Libraries of Central Europe (University Park, PA: Penn State University Press, 2008), chaps. 3 and 9. MS Biblioteca Apostolica Vaticana, Pal. Lat. 1375, fol. 19r. about which, see also: Láng, Unlocked Books, 132. MS BAV Pal. lat. 1375 f. 270v, on which: Láng, Unlocked Books, 117.

147 Hartmut Beckers, "Eine spätmittelalterliche deutsche Anleitung zur Teufelsbeschwörung mit Runenschrift-verwendung," Zeitschrift für deutsches Altertum und deutsche Literatur 113 (1984): 136-145.

148 Dresden, Sächsische Landesbibliothek N. 100, fol. 198r-20ov; BAV, Pal. lat. 1439, f. 346r-347v. Beckers, "Eine spätmittelalterliche deutsche Anleitung."

149 Gilles le Pape, Les écritures magiques (Milan: Arché, 2006). 
Encrypting methods in these cases do not in the least seem to be used as means for hiding information. This is not only because these cipher alphabets are easy to break, but also because the accompanying text, which is left open, clearly reveals what the coded text is about. Ciphers make no content inaccessible. It seems very likely that the special characters used to denote or conjure up the magical content of the spiritual world in effect worked to call attention to the ritual of the text, rather than hide it. Their mysterious appearance worked more like a strategy of exposure, an advertisement by means of the rhetoric of secrecy. The purpose of using special letters was not so much to satisfy cryptographic needs as to provide a channel of communication with the spiritual world.

\subsection{Encrypting in religion}

Cryptography and religious practice were rarely paired. Three examples will be introduced though, but none of them really fit the framework of this study in the strictest sense. The first example is from a period beyond the early modern era, the second is - most probably - from an area outside Hungary, and the third one cannot be clearly classified as cryptography. The reason for including them is rather that they all add important aspects to the relationship of secrecy, cryptography and religion.

The first is a rather unusual writing of Ladislaus Simandi (or László Simándi: 1655 - 1715). Simandi was a Pauline monk of Croatian origin who wrote in Hungarian and Latin. Selecting from an array of shaped poems, acrostics and other visually exciting short writings, he edited a volume for his students praising Saint Paul, the monk, and thus carving out his place in the early history of Hungarian and Croatian visual poetry. ${ }^{15^{\circ}}$ Into the selece tion of his own visual poems he inserted a poem made by using a cipher, in which he assigned numbers to the letters of the alphabet in an increasing order. 


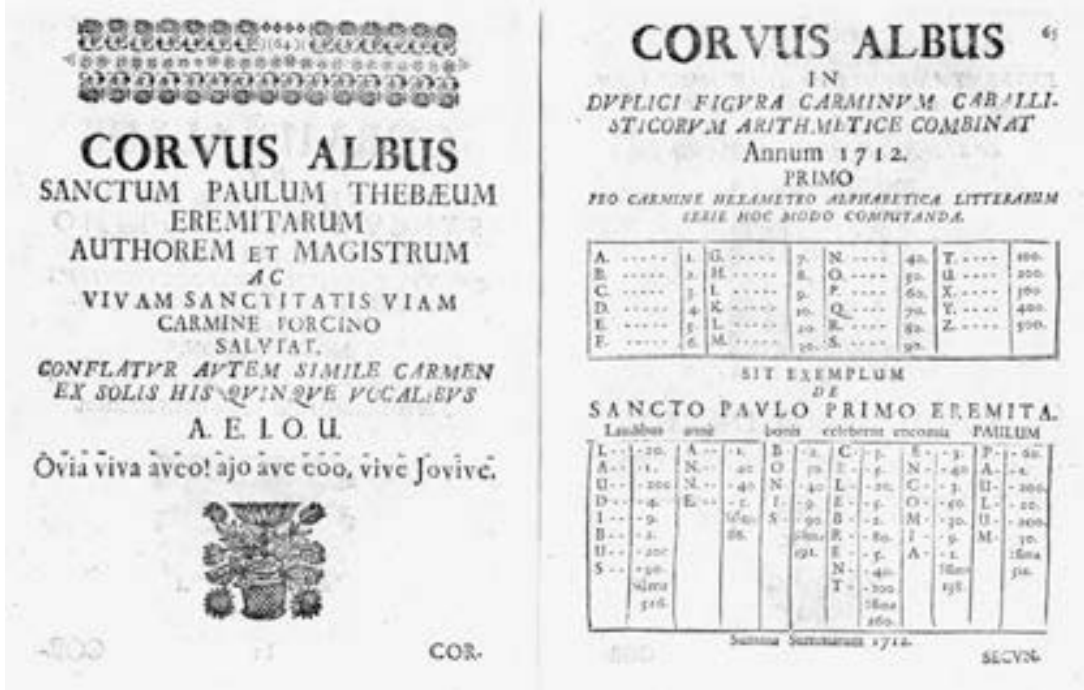

Versus cabalisticus: Ladislaus Simándi, Corvi albi eremitici nova Musa inconcinna 65.

The second example is from the letters of János Zakarjás (1720?-1772), a Jesuit priest, ${ }^{151}$ written to his superior from Peru, where he was working as a missionary between 1749 and 1756 , a few decades after our examined period.$^{152}$ He provides detailed accounts of the everyday problems and conn flicts of missionary life on the South-American continent, including his life among the Amerindian people, their various healing, funeral and other practices, as well as of his breathtaking travels from Genoa through Cadiz, Cordoba and Panama to Lima. The generally decent and 'comme il faut' Latin text is interspersed with less appropriate Hungarian expressions. In certain places he toys with such insertions, showing his real self to be less official in Hungarian than the rest of the letters in Latin would make us believe: "We were crawling on all fours all day." In other places he writes about Hungarian-related things or his own emotions in Hungarian, "God knows, if I will ever see Hungary again." He calls a certain lady honorable in Latin, to which he adds in Hungarian "the old hag". Describing a greying Saracen he bashfully adds in Hungarian that he was "walking up and down

151 I thank Gábor Farkas Farkas for calling my attention to this source. Ödön Sztankovics, ed. “Zakarjás János és Fáy Dávid délamerikai jezsuita misszionáriusok úti levelei (1749-1756)” (Travel letters of missionaries János Zakarjás and Dávid Fáy), Földrajzi Közlemények $3^{8}$ (1910): 115-128, 215-236. The manuscript of the diary: ELTE University Library, G. 689.

152 Letters of Zakarjás in Latin: Lajos Boglár, "The Ethnographic Legacy of Eighteenth Century Hungarian Travellers in South America", Acta Ethnographica, 1955, 313-358. 
the seashore stark naked like Adam in Paradise." One of his comments, however, makes it clear that he uses the Hungarian language not only as a game but also as a tool for secrecy: here he shares his suspicion with his addressee that his letters are being captured. ${ }^{153} \mathrm{~A}$ particular situation: the natural language of Hungary becomes a tool of cryptography in a remote part of the world, making the intimate content of the letters inaccessible for fellow missionaries.

Zakarjás goes deeper in cryptology: when he describes the cruelty of Brazilian slave merchants and fake missionaries, presumably fearing his own life too, he uses Hungarian Runic letters to write the Latin text, "Because malicious people have come over from Brazil, who have treated me too worse than you treat a tiger. They were Christians, not even Indians (he writes in Hungarian). They usually captured anyone whom they came across and took them to work in the mines (in runes), and other miserable places (in runes), they take the lives (in runes) of the elderly (in runes) to stop them from spreading word about them, they take the fingers (in runes) of others with which they would draw the archery bow, they take the mothers (in runes) more fit for travel by tearing their babies from their breasts (in runes) and slamming them at the first pole they find. And to deceive the careless people more, they sent one of their people ahead who pretended to be a missionary (in runes) in his clothes and appearance." He ends by giving his brother the key to the secret writing, specifying the well-known books where the Hungarian Runic alphabet is described. He uses a writing that he expects his addressee to be familiar with, but which is also completely inaccessible in South America.

This cannot be said of the third example for religious cryptography, the puzzling Rohonc codex, which got a membership in the elite club of unsolved ciphers.

This manuscript is a nearly 45o-page long handwritten book filled with 9-14 lines of unknown sign strings on each page and more than 8 o illustrations. ${ }^{154}$ The first and last few dozen pages have been detached from the book itself, and the original order of these pages is not known. There is no title page. Nothing is known about the provenience of the manuscript. It was donated to the Library of the Hungarian Academy of Sciences together with the 3000o-volume library of the late Hungarian Count Gustav

153 Sztankovics, "Zakarjás" 117-119, 216-220.

154 The manuscript is kept in the Manuscript Library of the Hungarian Academy of Sciences. Its call number is: $\mathrm{K} 114$, microfilm call number: MF 1173/II. A description of the codex can be found in: Csapodi Csaba, A “Magyar Codexek," elnevezésü gyứjtemény (K31-Kin4), (Budapest: MTAK, 1973), 109. 
Batthyány in 1838 . This library was earlier located at the family residence in the town of Rohonc (today: Rechnitz, Austria), hence the name of the codex. The Batthyánys had amassed their book collection from a great array of sources through a succession of centuries, so there is no guarantee that the codex is from either Hungary, or somewhere from Central Europe. Since, however, it came to Budapest from a then-Hungarian town, it deserves a place in the study on Hungarian secret writings.

The codex became the center of academic attention soon after its appearance, but only as long as it was considered to be a potentially valuable ancient Hungarian writing. The initial enthusiasm soon died out, and gave place to disappointment, skepticism and suspicion. By the end of the nineteenth century the academic public had decided to regard it as a forgery, so no serious scholar had studied it for a long time, until the turn of the twentieth and twenty-first century. ${ }^{155}$

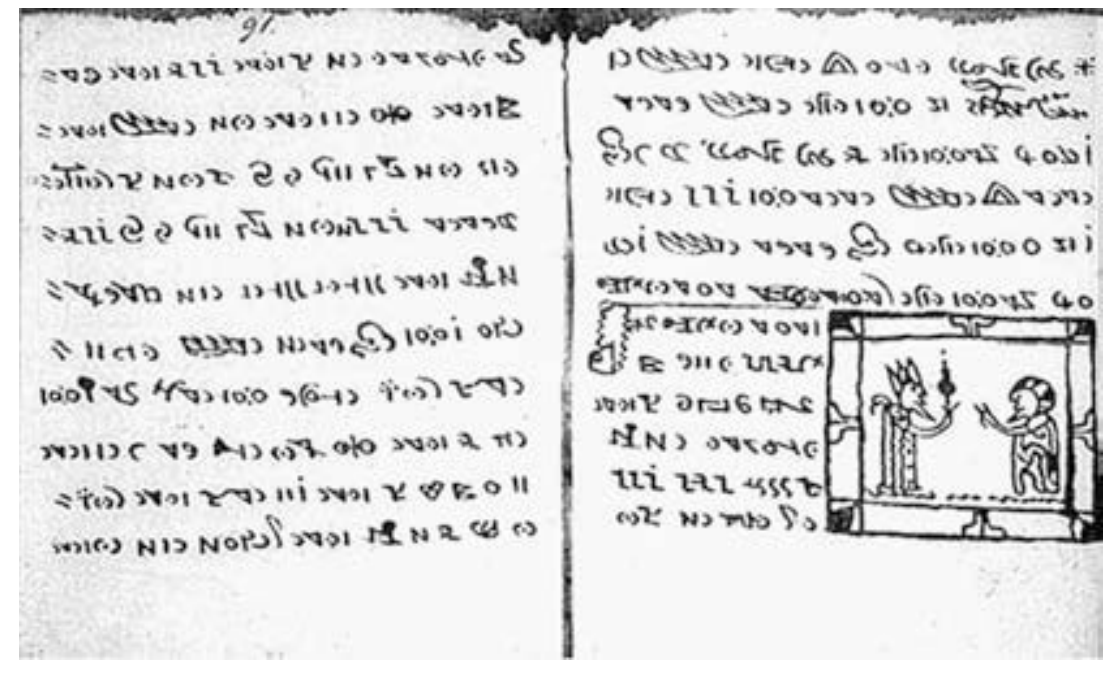

Two pages of the Rohonc codex (91-91a)

Having examined the regularities of the character strings in depth, the literature of the codex today agrees that the ciphered text is neither a forgery, nor a hoax, but carries decipherable real content. Having too many

155 See also: Benedek Láng, “Why don’t we decipher an outdated cipher system? The Codex of Rohonc" Cryptologia 34 (2010): 115-144. Gábor Tokai, “Az első lépések a Rohonci-kódex megfejtéséhez", (First steps towards the solution of the Rohonc codex), Élet és Tudomány LXV/5253, LXVI/2 (2010-2011): 1675-1678. and 50-53. Levente Zoltán Király, "Struktúrák a Rohonci-kódex szövegében." (Tructures in the text of the Rohonc codex) Theologiai Szemle 54 (2011/2): 82-93. 
characters with too few combinations, and lacking spaces between the words, it does not look as if it were trying to convince the reader that it had been written in a natural language. Neither does it seem to have been created to be sold for a fortune to a collector of old books and rarities. In this sense it does not appear to be a hoax either, because with its simple gray bind it looks neither valuable, nor mysterious, not counting the fact that it had been written with unknown characters. Obvious differences can be spotted when comparing the codex to the Voynich Manuscript, with its decorous appearance, and illustrations of mystical galaxies, botanical creatures and nude ladies.

The argument that the codex was written by a lunatic in his enthusiasm cannot be verified. To begin with, it must have been written by several people, which would require the cooperation of a group of nutty maniacs. And even if it was indeed written by one person alone, the returning "grammatical" structures indicate that no spontaneous automatic writing was employed, the author had instead applied certain pre-established rules in the process of writing. For this same reason, the consistent use of the combination of characters convinces me that the old hoax-theory can be completely dismissed. The writer was following a meaningful text, assigning the characters to the various items of this text. Nobody is able to note down such meaningless strings of characters with such rigorously followed rules.

The codex is most certainly a system of code-signs that is the result of a cipher, stenography or structured language.

Can the Rohonc codex possibly be a cipher? The text was obviously not produced by using a simple monoalphabetic cipher. It has way too many characters for that, way too strong repetitions, and a frequency chart that resembles no other natural alphabet. Running a consonant test yields no result either - vowels and consonants cannot be identified, and the entropy of the text is so low that the possibility of the polyalphabetic methods can be ruled out, too. A procedure that employs several alphabets would hide the patterns of the text well. But the codex is full of quickly returning sections with fully or partially identical structures, paragraphs or at least beginnings.

Could the codex have been coded in a homophonic cipher? An important argument for the homophonic system is that one gets the impression that certain signs stand for letters, but not every sign behaves like this: a good number of them seem to denote complete concepts or word parts. A study of the characters also indicates that certain signs could be left out, as if they carried no meanings, just like nullities. If this assumption is right, and the Rohonc codex contains a complex homophonic cipher, then 
the text should mostly have signs for letters and syllables, and partially for words. The letter-frequency and consonant tests, however, yielded no valuable information in this respect. Certain symbols clearly stand for the names of Christ and Pilate, but whether these could be regarded as nomenclatures is dubious.

The reader of the codex gets the impression that perhaps it is not only the single characters that carry a meaning, but often pairs of symbols, or perhaps triples or quadruples of them. Looking at the composite signs, a rather complex syllable-coding method might emerge. Assuming that sometimes single signs stand for syllables and double signs for single letters also explains the frequent repetitions.

Two further possibilities should be mentioned. The first is that we are dealing with a mere consonant-writing. Since this is basically the same as assuming that the codex was written in shorthand, this will be discussed below. The second is that nomenclatures dominate the text to such an extent that signs for letters are almost completely missing, and the system is virtually made up of word signs, in other words, codes. Such a code system, which requires an enormous amount of work and a good deal good luck to be broken, poses problems similar to that of a structured language, so it should be approached as such.

Could the Rohonc codex be an example of the multiple stenography systems popular in the seventeenth century? The obvious topic of the codex, Christian liturgy does not exclude this option. Shorthand systems were as regularly used for recording prayers and other religious purposes as for making records.

When Reverend James Humphrey left his Massachusetts home in ${ }^{1776}$ to fight for independence of his country, he was thoroughly familiar with Stenography Completed, the 1727 work of James Weston, so he could use this method to record the religious experiences he had in between the fights. Reverend Alexander Ewing used the method of John Byrom around 1780, and Reverend James Hawkes used that of Henry Barmby for similar purposes.

In these cases making the personal message discreet was just as important as increasing the speed of writing, if not more..$^{15^{6}}$ It was also not inn frequent for a designer of a shorthand system to illustrate the advantages of his work on the Lord's Prayer or other Biblical texts, ${ }^{157}$ even complete

156 Eric Sams, "Cryptanalysis and Historical Research," 94.

157 William Fordyce Mavor, Universal Stenography, or a new compleat system of short writing (S. l.: Harrison, s. d.). 
gospels were printed in shorthand. ${ }^{15^{8}} \mathrm{~A}$ fragment from the Bible from 1886 uses Pitman's system to code the New Testament. ${ }^{159}$ The basic constituents of the symbols are simple, but the characters that they make up are rather complex, and, due to the regularities of the text, they are repeated every so often. Just by looking at the pages of the shorthand gospel without the character table one gets lost pretty easily and cannot decide how to decipher the character strings.

There are several arguments, however, against the theory that the Rohonc Codex would be a shorthand scheme that we have no key to. Shorthand systems are meant to be economical and they are fundamentally letter-based, even if they do contain many abbreviations and word signs. The characters of the Rohonc Codex (those that appear to be basic units), are not in the least stroke-like. On the contrary, most of them take a lot of time and effort to draw. This makes this writing slow, whereas the vital feature of shorthand is that it is fast. Furthermore, shorthand systems are usually not secretive, this is why they leave plain texts and recognizable numerals in the text, as page numbers, for example (even if many shorthand systems do offer signs to be used for numbers too). They aim at teaching the reader, not excluding him. This, however, cannot be said of the Rohonc Codex, where there are no signs, page numbers, chapter headings, or enumerations that would refer to the cultural background of the codex. Finally, shorthand systems basically go from left to right, which is the way for right-handed people to write quickly without smearing the ink, whereas the text of the codex is written from right to left.

It is not entirely excluded for the Rohonc codex to be an early and not widespread shorthand design that cannot or does not wish to be as practical as more successful systems, and which is more secretive in nature, like Pepys's system of nullities. One can presume that the author was trying to put into practice a language constructed by himself, and this idea leads into the next topic, that of artificial languages.

How could one decide whether the Rohonc codex was written in such an artificial language? The fact that the text is totally incomprehensible does not rule out the possibility of human design. Some of the most well-known and "most philosophical" constructed languages also look bewildering

158 The New Testament of our Lord and Saviour Jesus Christ in Taylor's system of Short Hand as improved by George Odell (London: G. Odell, 1843). For this rare text, see Bibliothèque Sainte Geneviève, Paris, Réserve, delta 68223.

159 The new testament of our Lord and saviour Jesus Christ, printed in en easy reporting style of phonography by Isaac Pitman (London: Frederick Pitman, 1886), Bibliothèque Sainte Geneviève, Paris, Réserve, delta 68226 . 
without their key, their pictograms do not resemble anything, their structure seems illogical for the superficial observer. Only the most talented and lucky codebreaker would be able to break the languages constructed by Kircher or Wilkins. The idea therefore, that the codex is written in such a constructed language is not to be discarded. His author perhaps did not want to conceal or encrypt anything, it is just our bad luck that the table for the character keys and the description of the system are missing. Not even the absence of spaces should necessarily indicate intentional secrecy. The majority of structured languages does not intentionally hide spaces (why would they?) but neither do they emphasize them more than the Rohonc codex does.

Historians of structured languages distinguish between a posteriori language designs (that are based on existing languages) and the more "philosophical" a priori ones (those that are not). The codex does not seem to belong to those languages that have been designed in search of the lost ancient languages of Adam. Nor does it belong to the philosophical languages designed by Wilkins that offered to classify the entire world. ${ }^{160}$ Most likely it is one of the seventeenth-century attempts to create a common writing that is more practical than perfect. ${ }^{161}$ These focused on producing such a character-writing that everybody can read in their own language, therefore the name "universal character" or "escriture universelle" (universal writing). Such a system would need a very high number of characters to cover all the different basic concepts and verbs, as pointed out by Francis Bacon and John Wilkins too. ${ }^{162}$

The most famous of the many common writing projects is the Common Writing of Francis Lodwick. Many of these designs, however, were never printed. We know from scattered correspondence that in the years around 1630 three Frenchmen, des Vallées, Jean le Maire and D. P. Champagnolles, an Englishman, Philip Kinder, an Irishman, the Reverend Johnson, and a Swedish writer, Benedict Skytte, all working independently, came up with a version of artificial language where the words are represented by symbols. Sadly, none of these have survived - perhaps they were not all completed, perhaps they are lost or are still lying in oblivion in a manuscript library somewhere. ${ }^{163}$ Champagnolles' language design must have been pretty

160 Slaughter, Universal languages and scientific taxonomy.

161 Knowlson, Universal Language Schemes, chapter 2.

162 Ibid. $53-56$.

163 Slaughter, Universal languages and scientific taxonomy, 109-120. Rhodri Lewis, Language, Mind and Nature: Artificial Languages in England from Bacon to Locke (Cambridge: Cambridge University Press, 2007), 24-42. 
good since he could translate Homer's Iliad for King Charles I with no problem. Still, it was never published, for his widow had asked for too large a fee for it. Another language, Reverend Johnson's Wit-spell was withheld for technological reasons - its characters were simply too elaborate to be typeset. The Rohonc codex' text could be any of these projects, or even the end product of a seventh!

The chronology may undermine this hypothesis. The known history of universal languages in Hungary started a long time after the presumed birth date of the Rohonc codex, and they were considerably more primitive than the codex, except for one (Georg Kalmár's version), which was very complex, but not completely finished. Nevertheless, there may have been similar unpublished designs even in the Central European region. Or perhaps this language may have been created in Western Europe in the early $17^{\text {th }}$ century, either by an author whose other books are known today, or by someone whose name we have not yet heard of.

Accepting the assumption that the Rohonc codex is an artificial language put into practice, one is right to assume also that its characters or combination of characters stand for complete words, concepts, frequent connectives and pronouns. It is quite possible that its symbols denote the words of a universal language instead of the letters of a particular natural language. If this was the case, one would need a dictionary for this language, a list that assigns the combination of characters to our modern-day concepts. In the language designs that survived intact, this list is made up of several thousand items - in the thick book of Wilkins the lexicon alone makes up almost three hundred pages.

In conclusion, one should not expect the codex to behave like a cipher in which the letters are coded and where nomenclatures only make up the minor part of the text. One should rather treat the text as a code language where the whole words and sentences are the single units, and the letter-by-letter cipher text is the minority. As a result, tools of codebreaking should be used, and not those of cryptanalysis (frequency analysis, vowel test, word-pattern analysis and so on). The initial and ending character strings standing before and after the illustrations are very often repeated with smaller or bigger variations, so they offer themselves as good starting points for breaking the code ${ }^{164}$ just like the character strings (also repeated with small variations) identified as numbers. ${ }^{165}$

164 Such as on pages 6oa, 64a, 65, 68a, 69, 69a, 71, 72, 89a, 91a, 93a, 96, 98 .

165 Gyürk Ottó, "Megfejthető-e a Rohonci-kódex?" (Is the Rohonc codex decipherable?) Élet és Tudomány 25 (1970), 1923-1924. 
Studying these led both Gábor Tokai and Levente Zoltán Király to find a breaking point, first working independently, later in cooperation. They have identified the numeral system of the language, the names of the evangelists mentioned in the text, and have reconstructed the order of the loose pages. They have started the compilation of the code dictionary mentioned above. This research demonstrates that the text contains strong structures and therefore cannot possibly be the work of a lunatic. It is a structured and planned text that describes a given content: a religious text, a Bible commentary with a collection of prayers. ${ }^{166}$ 